\title{
Ius Civile'nın Tanıdığı Azat Etme Muameleleri ve Özel Hukuk Bakımından Sonuçları
}

\author{
G. Burcu Günveren ${ }^{*}$ ()
}

Öz

Roma'da kölelerin emeğine ihtiyaç duyulması sebebiyle, kölelik bir müessese olarak varlığını her zaman korumuştu. Bununla beraber kölenin hayatının bir aşamasında hürriyetine kavuşması da mümkündü. Efendinin çeşitli sebeplerle, kölesine hürriyet bahşetmesi oldukça önemli hukuki sonuçlar doğururdu. Köle, ius civile'nin aradığı muamelelerden biri ile azat edilmiş ise, vatandaşlık da kazanarak, Roma civitas'ına dâhil olurdu. Bir başka ifadeyle, azatlı (libertinus) olarak hayatına devam eden eski kölenin, hukuki statüsü değişir ve devam eden hayatında "kişi" sayılarak hak ehliyetine sahip olurdu. Dolayısıyla azat etme muameleleri ve sonuçları, Roma toplumunda oldukça önemsenmiş ve muamelelere kamu otoritesinin müdahalesi söz konusu olmuştu. Diğer yandan azatlının hayatının bir döneminde köle olması sonraki hayatını da olumsuz etkilemişti. Roma toplumunda özellikle ilk dönemlerde eski efendilik hakkı (iura patronatus), azatlının kazandığı hürriyeti olumsuz yönde etkileyebilecek türdendi.

Roma hukukunda köleler, hukuki bakımdan mal statüsünde idi ve ancak bir hakkın konusu olabilirlerdi. Kölelerin hürriyete kavulması "manumissio (azat etme)" denilen bir hukuki muamele ile olurdu. Efendinin, köleyi hürriyetine kavuşturacak olan hukuki muameleyi gerçekleştirmesinin sebepleri dönemlere göre farklılık gösterebilmekteydi. Kölenin sahibi olan efendinin, kölesine hürriyet tanımak iradesiyle, ius civile'de öngörülen biçim ve usullere uygun olarak gerçekleştirdiği manumissio, kölenin hukuki durumunu değiştiren bir muameledir. Söz konusu muamele ile köleye vatandaşlık da tanınırsa, azat edilen eski köle, hukuken "haklara ehil" bir başka deyişle hak ehliyetine sahip kişi durumuna gelirdi. Bahsedilen şekilci muameleler, en eski azat etme yöntemleri olan manumissio vindicta (değnekle azat etme), manumissio censu (sayım yolu ile azat etme), manumissio testamento (vasiyetname ile azat etme) idi. Bu azat etme biçimleri dışında, efendinin kölesini hür ilan etmesi hukuken herhangi bir sonuç doğurmuyordu. Köle, efendisi tarafindan fiilen serbest bırakılsa bile, ius civile nezdinde yine köle olarak kalırdı. Bununla birlikte praetor'lar efendinin azat etme iradesini açıkça ortaya koyduğu bazı hallerde, köleyi mülkiyet iddialarına karşı himaye edince hür gibi yaşayan azatlılar ortaya çıkmışt. lus civile'nin öngörmediği bu yeni biçimler azat edilen köleye, hürriyetini bahşetmekle beraber Roma vatandaşlığı kazandırmazdı. Praetor Hukuku’na göre hukuki sonuç bağlanan azat etme biçimleri ise şunlardı: Manumissio inter amicos (dostlar önünde azat etme), manumissio per epistulam (mektupla azat etme), manumissio per mensam (sofrada azat etme).

Azat etme muamelelerinin özel hukuk bakımından bir takım hüküm ve sonuçları doğardı. Bu hüküm ve sonuçları, azatlı (libertus) ile eski efendi (patronus) arasındaki ilişki bakımından ve azatlı ile doğuştan hürler bakımından olmak üzere iki ayrı başlık altında incelemek mümkündür.

Azatlı ve eski efendinin ilişkisi fides temeline dayanır ve karşılıklı ahlaki bir takım vazifeleri doğururdu. Roma'da adetler gereği köleler azat edildikten sonra dahi efendiye tabi olmaya devam ederlerdi. Bu durum özellikle ilk devirlerde olağan karşılanırdı ve efendinin azatısı üzerinde sahip olduğu eski efendilik hakkı (iura patronatus) ile açıklanırdı. Söz konusu haklar, azatlı bakımından yerine getirmekle yükümlü olduğu obsequim ve reverentia ile operae borçlarını ifade ederdi. Bunun yanı sıra efendinin, azatlı öldüğü takdirde onun mirasına iştirak etme (bona) hakkı vardı. "Obseqium" ile çocukların ebeveynlerine (ve azatlıların kendilerini azat eden efendilerine ve çocuklarına) karşı göstermekle yükümlü oldukları hürmet ifade edilirken, "reverentia" ile çocukların ebeveynlerine ve azatlıların kendilerini azat eden efendileri ile çocuklarına karşı saygı gösterme yükümlülüğü ifade edilirdi. Dolayısıyla reverentia'yı obseqium'dan ayrı düşünmek mümkün değildir. Operae libertorum ise, azatlının hürriyetine kavuştuktan sonra eski efendisi için belirli gün sayısı kadar onun menfaatine yapması gereken hizmetleri veya işleri ifade ederdi.

Azatlının sosyal hayatta ve kamu hukuku alanında da doğuştan hürler kadar eşit olmadıklarını ifade etmek gerekir. Zira hürriyetlerini kazanmalarına rağmen daha önce köle olmaları yaşamlarını olumsuz şekilde etkilerdi. Örneğin seçilme hakları (ius honorum) yoktu, seçme haklarını (ius suffragii) kısıtlı kullanırlardı. Bir başka ifade ile kamu hukuku alanında ehliyetleri kısıtlı idi. Diğer Roma vatandaşları gibi (ius conubii) evlenme hakkına sahiplerdi. Bununla beraber, doğuştan

\footnotetext{
Sorumlu Yazar: G. Burcu Günveren (Dr. Öğr. Üyesi), Bursa Uludağ Üniversitesi, Hukuk Fakültesi Roma Hukuku Anabilim Dalı, Bursa, Türkiye. Eposta: gburcudogan@hotmail.com
}

Atıf: Günveren, G. Burcu, “lus Civile'nın Tanıdığı Azat Etme Muameleleri ve Özel Hukuk Bakımından Sonuçları”, İstanbul Hukuk Mecmuası, 76/2, 2018, 529-557. https://doi.org/10.26650/mecmua.2018.76.2.0020 
hür olanlar ile azatlılar arasındaki evliliklerin yasal olduğu kabul edilse ve cezaya maruz bırakılmasa da, Roma toplumunun hiçbir döneminde bu evliliklere sıcak bakılmazdı.

\title{
Anahtar Kelimeler
}

lura patronatus • Libertus • Libertinus • Manumissio vindicta • Manumissio censu (sayım yolu ile azat etme), - Manumissio testamento • Obsequim • Reverentia • Operae libertorum • Bona

\section{Manumissions in accordance with lus Civile and Their consequences in terms of Civil Law}

\begin{abstract}
As the slave labor was needed in Rome, slavery always existed as an establishment. In addition, it was possible for a slave to become free at a certain period of his life. When a master granted freedom to his slave due to various reasons, it would bear critical legal consequences. If such slave had been liberated based on one of the conditions required as per ius civile, he would have acquired citizenship and become a part of Roman civitas. In other words, leading his life as a freed man (libertinus), the former slave's legal status would change. Spending his life as a "person", he would be entitled to the capacity to have rights. Therefore, the emancipation processes and results were deemed very significant in the Roman society and the public authorities were involved in the procedure. On the other hand, the fact that a freed person was once a slave had a negative effect on the following periods of his life. Particularly during the first periods in the Roman society, the right of patronage (iura patronatus) was likely to affect the freedom acquired by the freedman negatively.

Under Roman law, slaves were legally regarded in the status of property and could be the subject of one right only. The freeing of slaves was only possible by a juridical procedure called "manumissio" (emancipation). The Master's reasons of having this juridical procedure put into practice to free her or his slaves varied in different periods. Manumissio, is the act of changing the legal status of the slave, which was held in accordance with the forms and practices stated in ius civile at master's will to grant her or his slaves the freedom. Were the slave registered as the citizen thanks to this practice, the emancipated old slave would become "competent for the rights", in other words, the person who has the capacity to have rights. These formal practices were the oldest emancipation methods - manumissio vindicta (emancipation by a stick), manumissio censu (emancipation by the inventory), manumissio testamento (emancipation by testament). Apart from these emancipation forms, master's freeing his slave did not bear any legal consequences. Even though the slave was emancipated by her or his master, $\mathrm{s} /$ he was accepted as a slave before ius civile. However, in some cases where praetors laid bare the master's will to emancipate, there appeared the freed slaves living as free when the slave was patronised against the ownership claims. Unanticipated by lus civile, these new forms did not grant the Roman citizenship to the emancipated slave along with the freedom endowed. These were the emancipation methods bearing legal consequences according to the Law of Praetor: Manumissio inter amicos (emancipation before the friends), manumissio per epistulam (emancipation by a letter), manumission per mensam (emancipation on the table).
\end{abstract}

The emancipation practices had some effects and bore some consequences with regards to the private law. It is possible to examine these effects and consequences under two headings, one of which is in terms of the relationship between the freed (libertus) and the old master (patronus) and the other one is of the freed and the free from birth.

The relation between the freed and the old master was based on fides and was bearing some mutual moral duties. It was customary in Rome that the slaves continued being liable to the master even after s/he was emancipated. This was seen as natural especially in the beginning and explained by the right of mastership (iura patronatus) of the master on her or his freed slave. These rights meant the tasks of reverentia and operae that the freed were supposed to perform. In addition to this, the master had the right to enter upon the inheritance (bona) when the freed died. While the word "obseqium" was used to refer to the respect that the kids were to show to their parents (and the freed to their masters and their children), the word "reverentia" was used to point out the obligation of showing respect that the kids were under to their parents and the freed to their masters and their children. Therefore it is impossible to think reverentia something different from obseqium. As for operae libertorum, it meant the services or works that the freed had to do for her or his old master for a certain period of time in her or his interest after $\mathrm{s} /$ he was emancipated.

It should be noted here that the freed were not as equal as the free from birth in both the social life and public law. Even though they gained their freedoms, their lives were negatively affected by the fact that they were slaves in the past. They were, for example, deprived of the right to stand for election (ius honorum), and would have a limited use of their rights to vote (ius suffragii). In other words, their capacity was limited within the public law. Like the other Roman citizens (ius conubii), they had the right to get married. Having said that, although the marriage between the freeborn and the freed were accepted as legal and not subject to any penalty, such marriages were never well received in any period of the Roman society.

\section{Keywords}

Iura patronatus $\bullet$ Libertus $\bullet$ Libertinus $\bullet$ Manumissio vindicta $\bullet$ Manumissio censu (sayım yolu ile azat etme) $\bullet$ Manumissio testamento $\bullet$ Obsequim $\bullet$ Reverentia $\bullet$ Operae libertorum • Bona 


\section{Genel Olarak}

Roma hukukunda hukuki bakımdan, mal statüsünde olan ve bu nedenle ancak hakkın konusu olabilen kölelerden, bağcllık ve zeytincilik gibi tarım işlerinden, maden ocaklarının işletilmesinden, Roma oligarşisine sunulan hizmetlere kadar çok geniş bir yelpazede yararlanılırd1 ${ }^{1}$. Roma toplumunda kölelerin emeğine duyulan ihtiyaç nedeniyle hukuki bir müessese olarak kölelik, mevcudiyetini daima korumuştu. Bununla beraber kölenin hürriyetine kavuşması ve dolayısıyla hukuki durumunun değişmesi imkânı da vardı. Köleler hürriyetlerine "manumissio (azat etme)" denilen bir hukuki işlem ile kavuşurlardı. Kölenin sahibi olan efendinin kölesine hürriyet tanımak iradesiyle, ius civile'de öngörülen biçim ve usullere uygun olarak gerçekleştirdiği manumissio, kölenin hukuki durumunu değiştiren bir muameledir. Söz konusu muamele ile köleye vatandaşlık da tanınırsa, azat edilen eski köle, hukuken "haklara ehil" bir başka deyişle hak ehliyetine sahip kişi durumuna gelir.

Roma hukukunda azat etme muamelelerin çok eski tarihlerden beri uygulaniyor olması, ayrıca azat etme yöntemlerinin çeşitliliği ve kolaylığı, Roma hukukunda kölelik sisteminin katı olmadığını ortaya koyar. Roma toplumunda kölelerin hayatının bir aşamasında hukuki durumunun değişebilmesi her zaman mümkün olmuştur. Doğuştan hür olanlarla (ingenuus) azatlılar (libertinus) arasında toplumsal ve özellikle siyasal haklar bakımından hukuki eşitsizlikler daima var olsa da, söz konusu muameleler sayesinde kölelerin Roma toplumuna dâhil olması sağlanmıştır. Roma köle toplumu içinde özellikle sivrilen yetenekli veya entelektüel kölelere, katı ve titiz bir seçimle, hürriyetin yanı sıra vatandaşlık da verilmesi Roma'yı güçlendirmiş olmalıdır. Zira Roma'nın küçük bir şehir devletinden, çabuk bir biçimde, geniş ve kalıcı bir imparatorluk sistemine dönüşme başarısı, sürekli olarak yeni toplumsal grupları ve güçleri, etkin bir seçimle kendine bağlama politikası ile açıklanmaktadır².

\section{Azat Etme Muamelelerinin Nedenleri}

Efendinin, köleyi hürriyetine kavuşturacak olan hukuki muameleyi gerçekleştirmesinin sebepleri dönemlere göre farklllık gösterebilmektedir. Kölelerin, iyi hizmet etmeleri ve uysal olmaları vesilesiyle, hürriyetlerini kazanmaya layı olmaları, azat etme muamelelerinin en önemli nedenlerindendir. Dönem yazarlarından Cicero, arkadaşına yazdığı bir mektupta (ad Familiares'te XIV.4'te), iyi hizmet ettiği için, hürriyetini kazanmaya layık olan kölesini azat etmesini tavsiye etmektedir.

Bunun dışında, Roma'da efendiler ile köleler arasındaki dostane ilişkiler, efendileri, azat etme muamelelerine iten güçlü bir motivasyon kaynağı idi. Efendileri

*Uludağ Üniversitesi Hukuk Fakültesi Roma Hukuku Anabilim Dalı Öğretim Üyesi.

Karoly Visky, "Roma Hukukunda Kölelik ve Serbest Meslekler", Çev. Bülent Tahiroğlu, İstanbul Üniversitesi Hukuk Fakültesi Mecmuas1, 1974, C. 40, S.1-4, s. 689.

2 Özcan Çelebican, "Roma Egemenliği: Yurttaşlık ve Kölelik”, Ankara Üniversitesi Hukuk Fakültesi Dergisi, 1943, C. 43, S.1, s. 311 . 
ile yakın ilişkiler kurma şansına sahip olan köleler bu bakımından daha şanslı idi. Efendi ile köle arasında bahsettiğimiz türden bir yakınlığın, azat etme muameleleri bakımından, kanunlarda dahi yerini bulduğunu görüyoruz. Yirmi yaşından daha genç olan efendinin, kölesini azat etmek suretiyle gerçekleştirdiği tasarruf muamelelerini kısıtlayan Lex Aelia Sentia ${ }^{3}$ da, efendi ile köle arasında özel bir bağın bulunması ${ }^{4}$ geçerli bir sebep sayılmıştı (D.11.2.13). Söz konusu kanun, evlenmek istediği kadın köleyi ya da kan hısımı olan köleyi azat etmek isteyen efendinin gerçekleştirdiği muameleyi hukuken geçerli kabul etmiştir. Bir başka ifade ile, kanunun aradığı koşullar karşılanamamış olsa da, efendi ile azat etmek istediği köle arasında bahsettiğimiz türden bir bağın bulunması, azat etme muamelesinin sonuç doğurması için geçerli bir neden olarak sayılmıştır (Gaius, Inst.1.19-21). Özellikle Cumhuriyet devrinde, örnekleri sıkça görüldüğü üzere, efendileri azat etme muamelelerini gerçekleştirmeye yönelten saiklerin başında, köleleri ile aralarında özel bir bağın bulunması gelir ${ }^{5}$. Efendilerinden uzak bir şekilde, büyük arazilerde ya da madenlerde beden gücü ile çalışan kölelerin azat edilme ihtimali ise her zaman daha zayıf olmuştur.

Cumhuriyet devrinin ilerleyen zamanlarında, Horace ve Cicero'dan öğrendiğimiz üzere, hukuki bakımdan kendilerine eşit olmayanları küçümseyen ve daha düşük statüde bulunan kimselerin, kendilerine hizmet etmesini olağan karşılayan Romalılar bulunduğu gibi ${ }^{6}$, Stoac1 felsefenin etkisi altında kalan ve kölelerin tabii hukuk gereği efendilerine eşit olduğunu savunan Romalılar da vard1 ${ }^{7}$. Bu felsefe akımının doğurduğu düşüncelerin etkisindeki kimseler, kölelere iyi muamele etmenin gerekli olduğunu düşünürler ve çalışkan kölelere hürriyetlerini bahşederdi ${ }^{8}$. Bu düşünceye sahip erdemli efendilerin, kölelerine hürriyet bahşetmesi, azat etme muamelelerinin altında yatan bir sebep olarak değerlendirilebilir. Bununla beraber, konuya kölelerin bakış açısıyla yaklaşan bu eğilimin dahi, o yüzyıllarda kölelik müessesesini reddetmediği, bir başka ifadeyle, zımni de olsa onayladığı gözden kaçmamalıdır.

Bu sebepler dışında, edebi metinler incelendiği zaman, yetenekli olan ve entelektüel birikime sahip kölelerin kısa sürede azat edildiği bilgisine sahip olmaktayız. Suetonius

\footnotetext{
Azat etme muameleleri bakımından, M.S. 4 tarihinde Augustus'un yürürlüğe koyduğu kanunlardan lex Aelia Sentia'nın getirdiği yeni bir başka koşul ise, azat edilmek istenen kölenin otuz yaş ve üzerinde olması idi (Gaius, Inst. 1.18 ve Ulpianus, Reg. 1.12). Lex Aelia Sentia uyarınca, ergen olmayan birinin hangi sebeple olursa olsun azat edilmesi mümkün değildi. Otuz yaşına ulaşmamış bir kölenin azat edilmesi ise, daha ziyade kişisel ilişkilerden doğan haklı sebeplerin (causae probatio), imperium yetkisine sahip bir magistra önünde kanıtlanması ile mümkündü. Efendinin, kölesini azat etme muamelesi hususunda, kölenin yaşına ilişkin getirilen bu sınırlamalar, 531 yılında Iustinianus'un kanunu tamamen ortadan kaldırmasına değin, yaklaşık beş asırdan fazla yürürlükte kalmıştı. Ziya Umur, Roma Hukuku Lügatı, İstanbul 1983, s. 114.

4 Özel bağ ile kast olunan, azat edilmek istenen kölenin, efendinin biyolojik çocuğu ya da kardeşi olmaș, yetiştirdiği çocuk olması ya da evlenme niyetiyle kadın kölenin azat edilmek istenmesi halleri idi (Gaius, Inst. 1.19-21).

Susan Treggiari, Roman Freedmen During The Late Republic, Oxford 1969, s. 16.

6 Antik çağ yazarlarından öğrendiğimiz üzere, kendileri de eski bir köle olan azatlılar, kimi zaman en zalim efendiler olarak karşımıza çıkmaktadır. Plinius, Naturalis Historia adlı eserinde (33.135'de) dört binden fazla köleye sahip azatlı Isidorus'u zalim bir efendi olarak betimlemektedir.

Cicero, De Provinciis Consularibus (10)'da ve Horace, Satires (2.7.75)'de.

Treggiari, s. 13 .
} 
(De Grammaticis, 3'te) ${ }^{9}$, azat edildikten sonra ün kazanan Latin dil bilimcisi Lutatius Daphnis'in, erken yaşta hürriyetine kavuştuğunu yazmaktadır. Staberius Eros ve Voltacilius Pilutus eğitim-öğretim faaliyetlerindeki nitelikleri sebebiyle, efendileri tarafindan, hürriyetleri bahşedilen kölelerdi ${ }^{10}$. Bu örneklerde gördüğümüz üzere, efendi sağlar arası bir muamele ile kölesine hürriyetini bahşederse, kölenin hizmetinden mahrum kalırdı ancak azatlı olarak yaşamlarına devam eden bu vasıflı kimseler, bahsedeceğimiz üzere, eski efendilerine karşı yükümlü oldukları borçlar sebebiyle, azat edilmelerinin ardından da efendilerine faydalı olurlardı.

Efendi, ölüme bağl1 tasarruf muamelesi şeklinde yapılan azat etme usulünü (manumissio testamento' da) ${ }^{11}$ tercih ettiği takdirde, hem kölesinin hizmetinden mahrum kalmadığı gibi hak ettiğini düşündüğü sadık kölesini/kölelerini, kendi ölümünden sonra ödüllendirmiş de olurdu. Bunun yanı sıra efendi öldüğü zaman, cömertliğine minnettarlık duyan azatlılarının katıldığı, kalabalık bir cenaze dolayısıyla gösteriş yapma beklentisi içinde olabilirdi. Bu beklenti, onu azat etme muamelesi yapmaya iten sosyal nedenlerden biri olarak belirlenebilir ${ }^{12}$. Diğer yandan azat edilme beklentisinin köleyi iyi hizmet vermeye teşvik edeceği ve kölelerin uysal olmasını sağlamak gibi bir amaca hizmet edeceği de açıtır.

Ekonomik nedenler, bir efendi için, onu azat etme muamelesi gerçekleştirmeye yönelten en önemli nedenlerden biri olabilirdi. Özellikle kalabalık sayıda kölenin hizmet ettiği geniş ailelerde, yaşlı ve hasta olan kölelerin bakımı masraflı idi. Üstelik böyle bir kölenin cazip olmaması nedeniyle, alım-satım sözleşmesine konu edilmesi mümkün olmayabilirdi. Bunun yanısıra, ius civile'ye uygun azat etme muamelelerinden biri tercih edildiği zaman, Roma vatandaşı da olan köle, bir dönem, devlet tarafindan yoksul kimselere yapılan tahıl yardımından (congiaria) faydalanma imkânına kavuşurdu. Böylece, efendi azat etme muamelesi ile hürriyetine kavuşan kölenin bakımı ve beslenmesi gibi masraflardan kurtulmuş olurdu. Dönem yazarlarından Suetonius'tan, İlk imparatorluk döneminde refah içinde olmayan efendiler arasında bu uygulamanın oldukça yaygın olduğunu ve hatta Augustus'un, tahıl yardımı ile destek verilenler bakımından azat edilmiş köleleri hariç tutmak suretiyle önlem aldığını öğreniyoruz ${ }^{13}$.

Bahsettiğimiz sebepler dışında, köleler, kendilerine efendileri tarafindan tahsis edilen peculium'u işleterek büyük kazanç temin ettikleri takdirde, ödül olarak azat edilebilirdi. Böylece bir bakıma adeta hürriyetlerini satın alabilme imkânına sahip

\footnotetext{
Metin için bkz. http://www.thelatinlibrary.com/suetonius/suet.gram.html\#3.

10 Metin için bkz. http://www.thelatinlibrary.com/suetonius/suet.gram.html\#13 ve http://www.thelatinlibrary.com/suetonius/ suet.rhet.html\#3.

11 Çalışmanın ilerleye bölümünde, sayfa 6 ve devamında, azat etme biçimleri açıklanacaktır.

12 Bülent Tahiroğlu, Roma Hukuku Dersleri, Tarihi Giriş- Hukuk Tarihi- Genel Kavramlar- Usul Hukuku, İstanbul 2012, s. 144-145.

13 Metin için bkz. http://www.thelatinlibrary.com/suetonius/suet.aug.html\#42.
} 
olurlard $1^{14}$. Bununla beraber, ilerleyen yüzy1llarda M.S. $357^{\prime}$ de, azat edilen kölenin değeri üzerinden hesaplanarak, değerinin yüzde beşine tekabül eden ve vicesima libertatis (aururum vicesimarium) adı verilen bir vergi düzenlenmişti ${ }^{15}$. Efendi, kölesini azat etmek için muameleyi başlatırsa söz konusu vergiyi öderdi. Bununla beraber köle, kendisi satın almak suretiyle hürriyetine kavuşursa, bu vergiyi bizzat kendisi öderdi ${ }^{16}$. Kanaatimce getirilen bu vergi, kölelerin hürriyetlerine kavuşmalarının önünde bir engel olarak düşünülebilir. Efendileri için iktisap organı gibi faaliyet gösteren köleler ya da vergi toplayıcıları olarak vazife yapan efendilerin hizmetinde olan köleler için ciddi bir miktar peculium tahsis edilmesi mümkün olurdu. Dolayısıyla bu kölelerin kendilerine tahsis edilen peculium'u işleterek para biriktirmesi ve hürriyetlerini efendilerinden âdete satın alması kolay olabilirdi. Ancak sıradan sayılabilecek bir kölenin, kendisine verilecek peculium ile, hürriyetini satın alabilecek parayı (ve tabi ki ödenmesi gereken vergiyi) biriktirmeden hayata veda etmesi de mümkündü.

\section{Azat Etme Biçimleri}

\section{A. Genel Olarak}

Roma hukukunda zamanla, köleye hürriyetini bahşeden, çeşitli azat etme biçimleri gelişmiştir. Pater familias'ın (dolayısıyla efendinin) özerkliğinin ve otoritesinin baskın olduğu Eski Hukuk Döneminde, azat etmenin ne şekilde yapıldığı hususunda bilgi sahibi değiliz. Bununla beraber aynı dönemde Yunanistan'da olduğu üzere, kölesine fili hürriyet vermek isteyen efendinin, azat etme iradesi ile köleyi terk etmesi esasına dayanan bir usul olmas1 muhtemeldir ${ }^{17}$. Efendisinin iradesi ile hürriyetini kazanan kölenin, ius civile nazarında da hukuki statüsünün değişmesi ve "şahıs" olarak kabul edilmesi ise, çok büyük bir imtiyaza sahip olması anlamına gelirdi. Zira ius civile'ye göre şahıs sayılması, vatandaşlık kazanması ile (başka ifade ile Roma civitas'ına dâhil olması ile) mümkün olabilirdi. Bununla birlikte, özellikle ilk devirlerde kavimsel özelliklerine ve geleneklerine bağlı olan Romalılar, bir başkasını Roma civitas'ına dâhil etmek suretiyle, ona, Roma vatandaşlarının kullanabildiği medeni ve siyasi haklara sahip olma imtiyazını bahşetmek hususunda çekimser davranıyorlard ${ }^{18}$.

Azat etmenin doğurduğu en büyük problem de köleyi vatandaş olarak Roma civitas'ına dâhil etmesi idi. Bu imtiyazı tanıma yetkisinin tek başına efendiye ait olması düşünülemezdi. Roma hukuk düzeni bakımından, bu imtiyazın tanınması,

\footnotetext{
14 Tahiroğlu, Roma Hukuku Dersleri, s. 144-145.

15 Duygu Özer Sarıtaş, Cumhuriyet Dönemi Roma Vergi Sistemi, İstanbul 2012, s.103.

16 Arnold M. Duff, Freedman in the Early Roman Empire, Oxford 1928, s. 29.

17 Bülent Tahiroğlu, "Roma Hukukunda Azat etmenin Tahditleri”, İstanbul Üniversitesi Hukuk Fakültesi Mecmuası, C.38, S.1-4, 1973, s. 524-525.

18 Kimi zaman da Romalılar, Roma vatandaşlığı ve buna bağlı hakların verdiği ayrıcalıkları tanımayı, sosyal, siyasi ve ekonomik bir araç olarak kullanıyorlardı. Michel Villey, Roma Hukukunun Güncelliği, Çev. Bülent Tahiroğlu, İstanbu 1985, s. 75; Fulya İlçin Gönenç, Roma'nın Vatandaşlık Politikası, Prof. Dr. Necip Kocayusufpaşaoğlu için Armağan, Ankara 2004, s. 663.
} 
pratik hayatta yaratılan şekilci biçimlerle, efendinin iradesine kamu otoritesinin eklenmesi suretiyle çözülmüştür. Böylece efendinin hürriyet bahşetmek istediği kölenin, hukuk nazarında da statüsünün değişebilmesi için, şekilci muameleler benimsenmiş ve Roma civitas'ının bu muamelelere taraf olması sağlanmıştır ${ }^{19}$. Bununla beraber ifade etmek gerekir ki, söz konusu muameleler ile azat edilmek istenen köleye vatandaşlik da bahşedilmesi, hürriyet ve vatandaşlığın ayrılamaz olduğu fikrinden kaynaklanmıştır.

Bahsedilen şekilci muameleler, en eski azat etme yöntemleri olan manumissio vindicta (değnekle azat etme) ${ }^{20}$, manumissio censu (sayım yolu ile azat etme), manumissio testamento (vasiyetname ile azat etme) idi. Böylece Cumhuriyet döneminden itibaren, azat etme, ius civile'nin aradığı bu biçimlerden biri ile yapılmışsa, köle efendisine tabi olmaktan kurtularak hürriyetine kavuşuyor aynı zamanda vatandaşlik kazanarak, haklara ehil duruma geliyordu ${ }^{21}$.

Bahsedilen azat etme biçimleri dışında, efendinin kölesini hür ilan etmesi hukuken herhangi bir sonuç doğurmuyordu. Köle, efendisi tarafından fiilen serbest bırakılsa bile, ius civile nezdinde yine köle olarak kalırd1. Bununla birlikte praetor'lar efendinin azat etme iradesini açıkça ortaya koyduğu bazı hallerde, köleyi mülkiyet iddialarına karşı himaye edince hür gibi yaşayan azatl1lar ortaya çıkmışt1. Ius civile'nin öngörmediği bu yeni biçimler azat edilen köleye, hürriyetini bahşetmekle beraber Roma vatandaşlığ 1 kazandirmazdi ${ }^{22}$. Bununla beraber, uygulanması daha kolay olan bu yeni azat etme biçimleri gelişince, geleneksel olan ve ius civile'de öngörülen azat etme biçimleri hantal kalmıştı. Praetor Hukuku'na göre hukuki sonuç bağlanan azat etme biçimleri ise şunlard1: Manumissio inter amicos (dostlar önünde azat etme), manumissio per epistulam (mektupla azat etme), manumissio per mensam (sofrada azat etme).

Ortaya çıkış tarihleri için kesin bilgiye ulaşmak mümkün olmasa da manumissio censu M.Ö. 578-535 yılları arasında hüküm sürmüş antik Roma kralı Servius Tullius 'a atfedilmektedir ${ }^{23}$; manumissio testamento'dan ise XII Levha Kanunlar1'nda dahi bahsedildiği bilgisine sahibiz ${ }^{24}$ ve manumissio vindicta, Cumhuriyet döneminin çok erken tarihlerinde de uygulanmakta idii ${ }^{25}$. Bu azat etme biçimlerinden hangisinin

19 Tahiroğlu, "Azat etmenin Tahditleri”, s. 525.

20 Manumissio in Ecclesia, Hristiyanlığın kabulünden sonra, imparator Constantinus zamanında kabul edilmiş bir usuldü ve değnekle azat etme yerine geçmişti. Özcan Karadeniz-Çelebican, Roma Hukuku, Tarihi Giriş-Kaynaklar-Genel Kavramlar-Şahsın Hukuku-Hakların Korunması, Ankara 1997, s. 143.

21 Azat etme, efendinin köle üzerindeki mülkiyet hakkından vazgeçmesinden ibaret değildi. Efendinin köle üzerindeki mülkiyet hakkından vazgeçmesi, kölenin hukuki durumunu değiştirmezdi. Efendinin köleyi azat etme iradesi olmadan sadece mülkiyet hakkından vazgeçmesi köleyi terkedilmiş mal (res derelicta) durumuna getirirdi. Res derelicta'nın mülkiyetine sahip olma iradesi ile fiili hâkimiyetini ele geçiren o mal üzerinde mülkiyet hakkını kazanırdı. KaradenizÇelebican, s. 135.

22 Salvatore Di Marzo, S., Roma Hukuku, çev. Ziya Umur, İstanbul 1959, s. 41 vd; Tahiroğlu, Roma Hukuku Dersleri, s. 145.

23 Halicarnassus'lu Dionysius, Roman Antiquities isimli eserinde 4,22,4'te anlatmaktadır.

24 Ulpianus, Regulae adlı eserinde 2,4'te bahsetmektedir.

25 Livius, 2,5,9'da bilgi vermektedir. Metin için kbz: http://www.thelatinlibrary.com/livy/liv.2.shtml\#5. 
daha önce uygulama alanı bulduğuna dair kesin bir bilgiye sahip olmamakla beraber, en eski biçimin manumissio vindicta olduğuna dair bir öngörüde bulunmak mümkün olabilir. Zira, Halicarnassus' lu Dionysius, Roman Antiquities isimli eserinde 4,22,4'te manumissio censu'nun Servius Tullius tarafindan uygulamaya konulduğunda, daha önce zaten hürriyetine kavuşmuş azatlılardan evlerine dönmek yerine Roma'da kalmayı tercih edenlere, efendilerinin arzusu hilafina da olsa, vatandaşlık verildiğini aktarmaktadır ${ }^{26}$. Söz konusu azat etme biçimi, efendinin ölümünden sonra hüküm ifade edecek bir muameleden (manunissio testamento) ziyade, derhal hüküm ifade eden manumissio vindicta' yı akla getirmektedir. Bununla beraber hukuk metinlerinde ne yazık ki hangi azat etme biçiminin daha önce uygulamaya konulduğu hakkında bizi aydınlatacak bir metin yoktur. Diğer yandan pater familias, Roma devlet örgütlenmesinin sürdüğü ilk yüzyıllarda, örgütlü bir devlet teşkilatının kurulduğu sonraki yıllara göre daha güçlü ve özerk idi ${ }^{27}$. Bu bilgi ışığında, censor ${ }^{28}$ un tek başına karar verdiği ve muameleyi sonuçlandırdığ 1 manumissio censu'nun, manumissio vindicta'dan sonra uygulamaya konulduğu çıkarımı yapılabilir.

\section{B. Manumissio Vindicta}

Geleneksel azat etme muameleleri arasinda manumissio vindicta, muhtemelen en sık tercih edilen muamelelerdendi. Zira manumissio censu, censor' un beş yılda bir yaptığı ve on sekiz aya yayılan nüfus sayımı esnasında mümkündü ve manumissio testamento tasarrufta bulunan efendinin ölümünden sonra hüküm ifade ederdi. Bununla beraber manumissio vindicta, imperium yetkisine sahip herhangi bir magistra önünde gerçekleşebilirdi. Dolayısıyla diğerlerine göre daha çabuk sonuç veren, hızlı ve kolay bir yöntemdi. Cumhuriyet döneminde dictator, praetor, consul' luk makamında olan magistra'lar, Principatus döneminin başında propraetor ya da proconsul makamında olan yöneticiler ${ }^{29}$, Augustus döneminde praefectus Aegypti ${ }^{30}$ söz konusu azat etme

26 Bu konuyla ilgili bilgi manumissio censu başlığı altında bulunabilir. Çalışmamızda "C" başlığı altında yeralmaktadır.

27 Nitekim buna benzer bir örnek ceza hukuku alanından verilebilir: Roma devletinde ceza yargılama örgütünün gelişimi, kamu otoritesinin aile reisi otoritesinin yerini almaya başlaması ile mümkün olmuştur. Devlet teşkilatlanmasının zayıf olduğu ve dolayısıyla aile reisi otoritesinin sınırlandırılamadığı eski dönemlerde, kişisel öç alma duygusunun çok güçlü olduğunu ifade etmek gerekir. Bu dönemlerde genellikle kısas usulüne göre yürüyen cezalandırma işlemi, yargılama yetkisinin bir magistra' ya bırakıldığı dönemlerde ancak hukuksal bir yargılamaya dönüşmüștür. Daha geniş bilgi için bkz: Sevgi Kayak, "Roma Ceza Yargılama Hukukunda Sorgulama ve Cezalandırma Yöntemleri”, Prof. Dr. Belgin Erdoğmuş’a Armağan, İstanbul 2011, s. 155-185. s.162.

28 Censor'luk makamı, MÖ. 367 yıllarında, praetor'luğun yanısıra, consul'luk makamının yetkilerini bölüştürmek amacıyla kurulan magistra'lıklardan biriydi. En önemli görevi askeri, siyasi, idari ve toplumsal bakımdan özel önem taşıyan, yurttaşların ve onların malvarlıklarının listesini yapmaktı. Böylece vatandaşların hak ve yükümlülükleri kolaylıkla belirlenir, kişisel servetler kayda alınır ve vergilendirme doğru şekilde yapılabilirdi. Zamanla censor'lar, senatus üyelerini saptamak ve kamu topraklarını yönetmek gibi yetkilere de sahip olmuşlardır. Gökçe H. Türkoğlu, "Roma Hukukunda Censor'lar", Prof. Dr. Belgin Erdoğmuş’a Armağan, İstanbul 2011, s. 257; Ziya Umur, Tarihi Giriş- Kaynaklar-Umumi Mefhumlar- Hakların Himayesi, İstanbul 1974, s. 35.

29 Pricipatus döneminin henüz bașında barıșın sağlandığı ve orduya gerek duyulmayan eyaletlerin yönetimi senato'ya bırakılmıştı. Bu eyaletlerin başına senatus sınıfına mensup özellikle praetor'luk ve consul'luk yapmış olanlar arasından bir yıl süre ile görevlendirilen valiler bulunurdu. Bu yöneticiler propraetor ve proconsul olarak anılır ve imperium yetkileri bulunurdu. Umur, Lügat, s. 171.

30 İlk imparatorluk döneminde eyaletler arasında Mısır'ın özel bir önemi vardı. Böylesine zengin bir coğrafyanın yönetimini Senatus'a bırakmak istemeyen Augustus, kendisine bağlı bir memur olan praefectus Aegypti'yi bölgeye yerleştirmişti. 
işlemini onaylamaya yetkiliydi. Cicero'dan öğrendiğimiz üzere, M.Ö. 59 y1lında kölesini proconsul'un önünde azat etmiştî ${ }^{31}$.

Manumissio vindicta muamelesi, farazi bir hürriyet davası şeklinde yürürdü. Kölesini azat etmek isteyen efendi, kölenin özgür olduğunu iddia edecek olan bir arkadaş1 ve köle, magistra önüne gelirdi. Dava, legis actio sacramentum'a dayanan in iure cessio muamelesi formunda görülürdü. Bir kimsenin yanlışlıkla köle olarak tutulduğunu saptamak ve aslında hür olduğunu kanttlamak için açılan davada olduğu üzere, efendinin arkadaşı (adsertor libertatis), elindeki değnekle köleye dokunarak "bu kişinin hür olduğunu iddia ediyorum" derdi. Efendi ise, "bu kişinin hür olmasını istiyorum" demek suretiyle iddiayı kabul eder ya da susarak karşı tarafın iddiasını zımnen kabul ettiğini gösterirdi ${ }^{32}$. Magistra, bu azat etmeyi hukuka uygun bulursa kölenin, özgür bir insan olduğu iddiasını onaylar ve ilan ederdi. Magistra'nın beyanı ile azat etme muamelesi sonuç doğurur ve köle hürriyetine kavuşurdu.

Levy- Bruhl, manumissio vindicta'nın varsayıma dayanan farazi bir dava şeklinde yürütüldüğüne ilişkin genel kanaate karşı çıkmaktadır ${ }^{33}$. Yazara göre, magistra'nın huzurunda kölenin özgür olduğunu iddia eden adsertor libertatis ve efendi arasında yürütülen bir dava söz konusu değildir. Zira manumissio vindicta hakkında bilgi sahibi olmamızı sağlayan kaynaklar (D.40.2; Ulpianus, Reg.1.17; Gai. Ins.1.17; Cicero, Att.7.2.8) adsertor libertatis' in muameledeki varlığından bahsetmemektedir. Muamele, aslında kölesine hürriyet bahşetmek isteyen efendinin bu yöndeki beyanının, devlet otoritesini temsil eden magistra önünde açıklanması ve onaylanması suretiyle cereyan etmektedir. Levy- Bruhl, manumissio vindicta'nın farazi bir dava gibi yürütüldügüne ilişkin genel kanaate karşı çıkarken, klasik metinlerde ve edebi metinlerde adsertor libertatis'in varlığından, kesin olarak bahsi geçmediğinden yola çıkmaktadır.

Bununla beraber, Cicero, ad Atticum, 7.2.8 de tam aksini iddia etmektedir ${ }^{34}$. Metni incelendiğimiz zaman Cicero'nun magistra olarak görev yaptığı esnada gerçekleştirdiği azat etme muamelesini hükümsüz kılmak için çaba sarf ettiğini görüyoruz. Cicero'nun, azat edildikten sonra kendisine karş1 operae (hizmet edeceğine) yerine getireceğine dair, yeminle taahhütte bulunan kölelerin taahhüdünü yerine getirmemesi nedeniyle, Atticius'a serzenişte bulunduğunu ve kölelerini cezalandırmak için azat etme muamelesini hükümsüz k1lmak istediğini anlıyoruz. Cicero, sonuca ulaşmak için, kendisinin, efendi olarak değil, magistra

Recai G. Okandan, Roma Amme Hukuku, İstanbul 1944, s. 219.

31 Metin için bkz. http://www.thelatinlibrary.com/cicero/att2.shtml\#18.

32 Alan Watson, A., The Law of Persons in The Later Roman Republic, Oxford 1967, s.191; William Warwick Buckland, The Roman Law of Slavery, New Jersey 2000, s. 441; Tahiroğlu , Roma Hukuku Dersleri, s. 144-145; KaradenizÇelebican, Roma Hukuku, s. 140.

33 Henry Levy-Bruhl, Quelques problèmes du très ancien droit romain, "L'affranchissement par la vindicte", Paris 1984, s. $56 \mathrm{vd}$.

34 Metin için bkz: http://www.thelatinlibrary.com/cicero/att7.shtml\#2. 
olarak muamelede bulunduğunu, dolayısıyla kölelerin hürriyetlerini iddia eden ve kendisinden isteyen bir adsertor libertatis' in de bulunmaması nedeniyle muamelenin hükümsüz olduğunu ileri sürmektedir. Bunun için, bir dönem praetor'luk yapan Drusus $^{35}$ 'un da görevi esnasındaki edictum ile belirlenen uygulamanın ayn yönde olduğunu hatırlatmaktadır. Bu ifadeler neticesinde hukuka uygun bir manumissio vindicta'nın ancak kölenin hürriyetini iddia eden adsertor libertatis' in de katılımı ile gerçekleşebileceği fikrine varmaktayız. Bununla beraber Cicero'nun yemin ettikleri halde taahhütlerini yerine getirmeyen azatlılarını cezalandırmak gayesiyle oldukça şekilci bir yorumla konuya yaklaştı̆̆ da düşünülebilir.

Cicero'nun metni dışında, manumissio vindicta ile ilgili bilinen bir başka metin ise Livius'a aittir. Ab Urbe Condita Libri adlı eserinde, 41.9.11'de, MÖ. 177 y1lında Roma vatandaşlığı kazanmak amacıyla yapılan manumissio vindicta muamelelerine mani olmak için çıkarılan bir Senatus consultum'dan bahsetmektedir ${ }^{36}$. Metin içinde geçen "in libertatem uindicaretur" sözcükleri, o dönemde yapılan azat etme muamelelerinde kölenin hürriyetini iddia eden bir adsertor libertatis' in varlığına işaret etmektedir ${ }^{37}$.

Kanaatimce, azat etme muamelelerinin yüzylllar geçtikçe in iure cessio muamelesi formundan ve hatta şekilcilikten uzaklaştığı gözden kaçırılmaz ise, Cumhuriyet döneminin sonlarında yaşayan Cicero'nun, kendi lehine yorum yaptığı yönündedir. Livius'un eserinde bahsedilen yıllarda -ki Cumhuriyet döneminin sonları olmakla beraber Cicero' dan önceye tekabül etmektedir-gerçekleșen manumissio vindicta' ların, halen in iure cessio muamelesi biçiminde yapılıyor olması muhtemeldir. Dolayısıyla kölenin hürriyetini iddia edecek olan adsertor libertatis'in muamelede varlığ söz konusu olabilir. Cumhuriyet döneminin son yüzyıllarını da içine alan Klasik hukuk döneminden itibaren ise, manumissio vindicta'nın in iure cessio formunda yapılmadığı genel olarak kabul edilmektedir ${ }^{38}$.

\section{Manumissio Censu}

$\mathrm{Bu}$ çeşit azat etmede, efendi, censor'un yaptığı nüfus sayımı esnasında, vatandaşlar için tutulan listeye kölesinin kaydedilmesini sağlamak üzere, censor'a, onu adeta hür bir kişi gibi takdim ederdi. Kimi zaman da bizzat köle, efendisinin emri ile ya da rızası ile kendisini takdim ederdi. Böylece, efendinin azat etmek istediği köleye, kendisini censor'a hür bir kişi gibi takdim edip, vatandaşlar listesine kayıt etmesine dair verdiği izin ya da emirden ibaret olan iussum ile başlayan muamele, censor' un vatandaşlığa layık bulduğu bu kimseyi bizzat listeye

\footnotetext{
5 M.Livius Drusus, muhtemelen MÖ. 120-115 tarihleri arasında devlet görevlerinde bulunmuş ve praetor'luk da yapmış devlet adamıdır. Akşit, Oktay, Roma İmparatorluk Tarihi, İstanbul 1985, s.17.

36 Metin için bkz: http://www.thelatinlibrary.com/livy/liv.41.shtml\#9.

37 Buckland, s. 442; Metin için bkz. http://www.thelatinlibrary.com/livy/liv.41.shtml\#9.

38 Watson, s. 193; Max Kaser, Römische Privatrecht, Munich 1955, s. 253.
} 
kayıt etmesi ile sonuçlanırdı. Bir başka ifade ile iussum, manumissio censu'nun gerçekleşmesi bakımından bir şart idi ${ }^{39}$.

Manumissio censu, beş yılda bir yapılması planlanan nüfus sayımı esnasında uygulanabildiği için, manumissio vindicta' ya nazaran daha kullanışsız bir yöntemdi. Üstelik, Cumhuriyet döneminin son yüzyılı gibi nüfus sayımının düzenli yapılmadığ 1 dönemler de vardı. Bunun yanısıra, Romanus civis (Roma vatandaşı) olarak listeye kayıt olmak mı yoksa sayımın süregeldiği on sekiz aya varan bir sürenin sonunda gerçekleşen lustrum ile mi kölenin hürriyet ve vatandaşlık kazandığı sorusuna da yanıt bulmak mümkün değildir ${ }^{40}$. Cicero da De Oratore isimli eserinde $(1,183$ 'de) aynı soruya yanıt aramaktadır.

Bahsedilen belirsizlik ve olumsuzluklara rağmen, manumissio censu'nun neden uygulamaya konulduğu ve neden rağbet gördüğü hakkında ise, yine Halicarnassus'lu Dionysius' un metnini esas alan Daube bizi aydınlatmaktadır ${ }^{41}$. Dionysius, manumissio censu muamelesinin Roma Hukuku'nda Servius Tullius'un reformları arasında yer aldığını aktarmaktadır. Yine yazara göre, bu azat etme biçimi Roma’yı terk etmek üzere olan azatlıları vatandaşlar arasına katmak amacıyla ortaya çıkmıştı (Dionysius, Roman Antiquities isimli eserinde 4,22,4'te). Dionysius'un aktardığı üzere, Servius Tullius, efendilerinin rizasina uygun olmasa bile, Roma'da kalmayı tercih eden eski kölelere, bu yöntemle vatandaşlık bahşetmeyi uygun görmüştür. Bir başka ifade ile manumissio censu, uygulanmaya başlanması ile, bir başka biçimle sadece özgürlüğüne kavuşmuş olan azatlılara vatandaşlık da tanımış olduğu için tercih sebebi olmuştu. Manumissio censu muamelesi ile birlikte censor' un census esnasinda Romanus civis olarak vatandaşlar listesine kayıt ettiği köle, hürriyetine de kavuşuyordu. Daube, manumissio censu'nun kendisinden önceki azat etme muamelelerinden farklı olarak sadece hürriyet değil, vatandaşlık da bahşetmesi nedeniyle rağbet gördüğünü ifade etmektedir ${ }^{42}$. Bir başka ifade ile manumissio censu, diğer azat etme muamelelerinden daha geç uygulamaya girmiştir ancak vatandaşlık ve hürriyeti birlikte bahşettiği için diğerlerinden farlılık arz etmektedir. Ayrıca Daube, yaygın görüşün aksine, manumissio censu ile vatandaşlık ve hürriyetin ayrılamaz hale geldiğini ve diğer azat etme muamelelerine örnek teşkil ettiğini düşünmektedir. Bununla beraber maalesef ki, Daube'nin görüşünü dayandırdığ 1 Dionysius'un metnini destekleyecek herhangi bir bilgi kaynağına, ne yazık ki, sahip değiliz.

Ulpianus'tan öğrendiğimiz üzere (Reg. 1,8) İmparator Sulla'dan sonra nüfus sayımı düzenli aralıklarla yapılmamıştı ve bu nedenle manumissio censu da

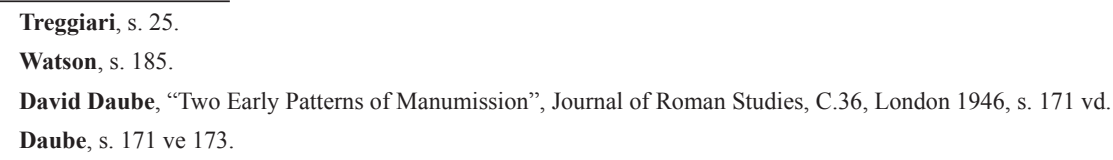


uygulamadan kalkmışt1 ${ }^{43}$. Kanaatimce, Daube'nin fikri kabul edilecek olursa, diğer azat etme biçimlerinin de vatandaşlık bahşetmesi ile manumissio censu eskisi kadar rağbet gören bir yöntem olmaktan çıkmış olmalıdır.

\section{Manumissio Testamento}

Manumissio testamento, efendinin ölümünden sonra hüküm ifade edecek olan vasiyetnamesinde açıkça belirtmek suretiyle istediği kölelerine hürriyet bahşetmesi idi. Böylece efendi ölümünden sonra hüküm ifade edecek olan vasiyetnamesinin muhtevasına azat etme işlemi ekleyerek, henüz hayatta iken, terekesini etkileyecek bir tasarruf işleminde bulunmuş olurdu. Geçerli olması için vasiyet eden efendinin, vasiyetnameyi düzenleme anında ve vefat anında azat edilmek istenen kölelerin mülkiyetine sahip olması gerekirdi. Vasiyet eden efendinin vasiyetnamesinde kullandığg ifadelere göre, köle özgürlüğünü ya doğrudan kazanır ya da vasiyet edenin mirasçıları azat etme işlemini yapard. Manumissio testamento, diğer geleneksel azat etme biçimlerinden şarta bağlanabilmesi açısından ayrılırdı. Böyle bir şart öngörülmüş ise, köle, şartın gerçekleşmesi anına kadar mirasçılara ait olmaya devam ederdi ${ }^{44}$. Şart gerçekleşince başka bir işleme gerek kalmaksızın hürriyetine kavuşurdu.

Daha önce ifade ettiğimiz üzere bu azat etme biçimi, vasiyet eden açısından, hürriyetine kavuşma beklentisi içinde olan uysal kölelere sahip olmak ve minnettar azatlılardan oluşan bir kalabalık ile uğurlanmak gibi imkânlar sunarken, mirasçılar açısından kölelerin hizmetlerinden mahrum olma ve vicesima libertatis denilen vergiyi ödeme yükümlülüğü gibi sonuçlar doğuruyordu. XII Levha Kanunlarında bahsi geçen manumissio testamento, azat etme biçimleri arasında en sık tercih edilen $\mathrm{idi}^{45}$ ve efendi hayatta iken hüküm ifade eden azat etme biçimlerinden daha sonra uygulanmaya başlandığı ihtimali akla uygun gelmektedir ${ }^{46}$.

Cumhuriyet döneminin sonlarına kadar, efendinin düzenlediği vasiyetname, altı ayda bir toplanan comitia calata huzurunda onaylanmak suretiyle geçerliliğe kavuşur ve vasiyet edenin ölümü halinde hüküm ifade ederdi. Bir başka ifadeyle, vasiyetnamenin geçerliliği, efendinin iradesini ifade eden vasiyetname içeriğinin halkın onayına sunulması ile gerçekleşen bir yasama faaliyetinin tamamlanmasına bağlıydı. Dolayısıyla vasiyetnamenin içeriğinde yer alan bir tasarruf işleminden ibaret olan azat etme işlemi, kamu otoritesinin tasdiki ile vücut bulurdu. Bununla

\footnotetext{
43 Di Marzo, s.43.

44 Efendi, azat etme işlemini şarta bağlayabildiği gibi vadeye de bağlayabilirdi. Söz konusu vasiyet gereği, kölenin sahibi haline gelen mirasçı ya da lehine belirli mal bırakılan kimse, şartın gerçekleșmesi veya vadenin dolması üzerine köleyi özgürlüğüne kavuşturacak olan azat etme işlemini yapma yükümlülüğü altında olurdu. Statuliber, kölenin, özgürlügünü beklediği bu zaman zarfında, içinde bulunduğu hukuki durumu ifade eden bir kavramdır. Daha geniş bilgi için bkz. Güzide Burcu Günveren, "Roma Hukuku'nda Statuliber", Marmara Üniversitesi Hukuk Fakültesi Hukuk Araştırmaları Dergisi, Prof. Dr. Cevdet Yavuz'a Armağan, C. 22, S: 3, 2016, s.1241-1257.

45 Watson, s. 194-195; Buckland, s. 459.

46 Treggiari, s. 28.
} 
beraber ifade etmek gerekir ki, Cumhuriyet döneminin sonlarından itibaren siyasi otoritenin ağırlık merkezinin değişmesi ve imparatorluk sınırlarına ulaşan Roma'da, comitia calata'nın toplanamaz hale gelmesi ile söz konusu kamu otoritesi kaybolmaya başlamıştı.

\section{E. Azat Etme Biçimlerine İliş̧kin Değerlendirme}

Azat etme biçimlerinden ius civile'nin de tanıdığı, geleneksel ve eski olan bu üç biçimde de, devlet otoritesinin muameleye dâhil olması gerekirdi. Manumissio vindicta, magistra'nın tasdiki ile sonuç doğururdu. Manumissio testamento'nun geçerli olması için, comitia calata'nın huzurunda vasiyetnamenin onaylanması gerekirdi. Manumissio censu ise diğerlerine göre özellik arz etmekteydi. Zira bizzat nüfus sayımı esnasında censor'un tek taraflı olarak gerçekleştirdiği bir eylemle sonuçlanırdi ${ }^{47}$.

Azat etme muamelelerini konu alan çalışmaları incelediğimiz zaman, farklı biçimlerde ortaya çıkan bu muamelelerin benzerlikleri vurgulanarak birbirlerine benzetilmeye çalışıldığı farkedilecektir. Örneğin Mommsen, manumissio censu ve manumissio vindicta'yı kastederek, bu iki azat etme biçimini "sağlar arasında azat etme muameleleri" olarak adlandırmaktadır. Yazar bu muamelelerde, praetor ile censor' un öneminden ziyade, efendinin önemini vurgulamaktadır. Zira aslında kölenin hukuk düzeni tarafindan kişi olarak kabul edilmesinin önünü açan husus, efendinin köleyi özgür olduğu varsayımı ile censor'a takdim etmesi ya da manumissio vindicta' da kölenin özgür olduğu varsayımı ile davanın yürütülmesi idi ${ }^{48}$. Bir başka deyişle öncelikle efendi, kölesinin özgür olduğunu açıklardı ve bunun gerçek olduğu varsayımı ile muamele yürürdü. Manumissio censu da, efendi tarafindan yaratılan ve faraziyeye dayanan bir olgunun, devlet otoritesini temsil eden bir görevli tarafindan kabul ve tasdik edilmesi ile sonuç doğurması bakımından manumissio vindicta'ya benzerdi. Bununla beraber, her iki muamele açısından da kölenin hukuki statüsünü değiştiren ve onun kişi olarak kabul edilmesi için gerekli olan muamelenin önünü açan efendinin iradesine dayanan bir beyan olsa da, köleye özgürlük ve vatandaşlık bahşeden magistra'nın onayıdır. Yazar bu hususu ise, manumissio censu'da kölenin özgür olduğu varsayımı ile vatandaşlar listesine kayıt edilmesinin vatandaşlık kazandırmadığııı, ancak vatandaşlık kazanmak için bir şans ve olasılık yarattı̆̆ını, nihayetinde listenin hazırlanıp sayım bittikten sonra yapılan lustrum merasiminin akabinde - sözkonusu süre on sekiz ayı bulabilirdi- censor'un kararı ile hürriyet bahşedileceğini ifade ederek vurgulamaktadır. Dolayısıyla, kölenin azat edilebilmesi için, efendi ile tercih edilen muameleye göre praetor ya da censor' un gerçekleştirdiği işbirliğine ihtiyaç vardır.

\footnotetext{
47 Daube, s. 57 vd.; Treggiari, s. 26.

48 Theodor Mommsen, Römisches Staatsrecht, Leipzig 1887, s. 374.
} 
Azat etme biçimlerinden manumissio vindicta anlatılırken izah edildiği üzere, Levy- Bruhl ise muamelenin, efendi ile adsertor libertatis'in karşılıklı işbirliğini gerektiren farazi bir dava gibi yürütüldüğü teorisini reddetmektir ${ }^{49}$. Yazarın bu yaklaşımı, bir açıdan manumissio muamelelerinin geleneksel biçimlerini tek bir forma sokmaktadır. Zira yazara göre de, manumissio vindicta, manumissio censu ve manumissio testamento, efendinin kölesine özgürlük bahşetme yönünde açıkladığ1 iradenin, ilkinde magistra, ikincisinde censor ve diğerinde comitia calata tarafindan tasdikinden ibarettir.

Sonuç itibariyle azat etme biçimlerini ele alan yayınları incelediğimiz zaman ${ }^{50}$ üç azat biçimini de "efendinin herhangi bir saik ile kölesine hürriyet bahşetme yönünde açıkladığ şeklinde özetlediğine tanık oluyoruz. Tüm bu azat etme muameleleri neticesinde Roma devletine bir vatandaşın katılıyor olması, devlet müdahalesini gerektirmiştir. Bir başka ifadeyle tüm azat etme biçimleri birbirine yakın bir tanımla, efendinin iradesi ve onay ya da kontrol vazifesi gören devlet otoritesi düzeyine indirgenmiştir.

Bununla beraber manumissio censu, diğer azat etme biçimlerden censor'un muamelede arz ettiği görev bakımından ayrılmaktadır. Censor, efendinin kölesine hürriyet bahşetme yönündeki iradesi ile başlayan muamelede tek başına hareket etmektedir. Diğer azat etme muamelelerinde ise karşıllklı bir işbirliğinden söz etmek daha uygundur. Efendinin azat etme yönündeki iradesi ile başlayan prosedür, devlet otoritesini temsil eden gücün onayı ile sonuç doğurmaktadır ve efendi, muamelede aktif rol alarak prosedürün bir parçası olmaktadır. Örneğin manumissio testamento'da, içeriği efendinin arzusuna göre şekillenmiş olan vasiyetin, kamunun menfaatini dikkate alan ve kamu otoritesini temsil eden meclise sunulması ve akabinde meclisin, vasiyeti (ve dolayısıyla içeriğinde yer alan azat etmeyi) onaylaması ile hukuki sonuç doğmaktadır. Buna benzer şekilde, manumissio vindicta' da da efendinin azat etme iradesinin magistra tarafindan onaylanması ile işbirliğini gerektiren bir muamele neticesinde, efendi sahip olduğu bir haktan vazgeçmektedir ve köle hürriyetine kavuşmaktadır. Oysa manumissio censu, censor'un ve efendinin karşılıklı gerçekleştirdiği bir muamele değildir. Nüfus sayımı esnasında efendinin hürriyetini bahşetmek istediği köleyi (ya da efendisinin emri ve izni ile vatandaşlar listesine kayıt olmak isteyen kölenin bizzat kendisini) censor'a takdim etmesi gerekmektedir. Roma devletinin siyasi örgütüne kimin katılabileceği hususunda tamamen bağımsız ve serbest takdiri ile karar verebilen censor'un, vatandaşlar listesine kayıt ettiği köle, hürriyete ve vatandaşlığa kavuşmaktadır. Bir başka ifadeyle, bu azat etme yönteminde censor, görevini icra ederken tek başına hukuki bir sonuç yaratmaktadır. Censor'un, kendisine hürmüş gibi takdim edilen köleyi, vatandaşlığa seçtiği için

\footnotetext{
$49 \quad$ Levy-Bruhl, s. 74.

$50 \quad$ Kaser, 253 vd., Levy-Bruhl, s.70-74; Daube s. 57 vd.
} 
ve vatandaşlar listesine kayıt etmesi nedeniyle, bir başka ifadeyle köle, censor'un hukuki fiili neticesinde, Roma devletine katılan hür kimse statüsüne kavuşmaktadır. Manumissio censu'da vatandaşlar listesine kayıt etme işlemi esnasında censor ve efendinin işbirliğinden bahsetmek, censor'un bağımsızlı̆̆ 1 ile bağdaşmayacaktır. Zira censor, bu köleyi özgürlük durumunu kazanmaya layık görmez, örneğin onun iyi ahlakl1, dürüst bir kimse olduğuna kanaat getirmezse, vatandaşlık bahşetmekten imtina edebilmektedir ${ }^{51}$. Diğer azat etme muamelelerinde efendinin hürriyet bahşetme yönünde iradesinin önem kazanması ve muameleyi kamu otoritesini temsil eden magistra veya kurum ile işbirliği içinde yürütmesi, ayırt edici esaslı noktayı oluşturmaktadır.

\section{Azat Etmenin Özel Hukuk Bakımından Hüküm Ve Sonuçları}

\section{A. Azatlı (Libertus) ile Eski Efendi (Patronus) Arasındaki İlişki Bakımından}

\section{Genel olarak}

Ius civile'ye uygun azat etme muamelesi neticesinde eski köle sui iuris hale gelirdi. Azat edilen köleye libertinus, kendisini azat etmiş olan eski efendi (patronus) karşısındaki durumu için de libertus denilirdi. Kendisini azat eden efendinin ya da başka bir gens'in üyesi sayılmazdı. Azatlı (libertinus), hayatının kalan kısmında kendi ailesinin pater familias'ı sayılırdı (D.28.1.14). Kadın köle ise, azat edildikten sonra eski efendisinin vesayeti altında olurdu.

Azatlıların, özellikle ilk yüzyıllarda kendilerini azat eden eski efendileri ile bağlarının kopmadığını ve hatta çoğunlukla birlikte yaşamaya devam ettiklerine dair bizi bilgilendiren metinler vardır (D.9.3.5.1 ve Aulus Gellius, Noctes Atticae 5.13). Kimi zaman efendiler yakın bağlar kurdukları azatlılarını mirasçı olarak atamışlardır (D.17.2.71.1).

Azatlı ve eski efendinin ilişkisi fides temeline dayanır ve karşılıklı ahlaki bir takım vazifeleri doğururdu. Roma'da adetler gereği, köleler azat edildikten sonra dahi efendiye tabi olmaya devam ederlerdi. Efendi, azatlısını korumak ve ona yardım etmekle yükümlüydü. Bununla beraber azatının, kendisine hürriyet bahşeden efendiye karşı vazifeleri çok daha ağırdı. Azatlının, çalışmamızın ilerleyen bölümlerinde ayrıntılı olarak bahsedeceğimiz yükümlülüklerinin yanı sıra, kendisini azat eden kadın ile veya azat eden erkeğin karısı veya alt soyu ile evlenmesini yasak eden prensip de aralarındaki yakın bağ sebebiyle ahlaki gerekçelere dayanırdı.

Gerçekten hukuki metinlerde de karşımıza çıktığ itibaren özellikle azatlının, efendiye karşı yerine getirmekle yükümlü oldukları

Karadeniz-Çelebican, Roma Hukuku, s. 141 
vazifeler bulunduğunu anlıyoruz. D.38.2.1.pr.'da Ulpianus, eski tarihlerden itibaren, efendilerin, Roma civitas'ına taşıdıkları azatılırına böyle önemli bir ayrıcalık tanımalarının bedeli olarak aşırı talepkar olmalarının bir alışkanlık olduğunu aktarmaktadır.

Efendilerin taleplerinin toplumda olağan karşılanması, efendinin azatlısı üzerinde sahip olduğu eski efendilik hakkı (iura patronatus) ile açıklanırd1 ${ }^{52}$. Söz konusu haklar, azatlı bakımından yerine getirmekle yükümlü olduğu obsequim ve reverentia ile operae borçlarını ifade ederdi. Bunun yanı sıra efendinin, azatlı öldüğü takdirde onun mirasına iştirak etme (bona) hakkı vardı.

Bununla beraber çok eski zamanlarda efendinin azatlı üzerinde sahip olduğu güç ve yetkinin ölüm-yaşam hakkına kadar uzandığı (ius vitae et necis) ifade edilmektedir ${ }^{53}$. $\mathrm{Bu}$ konuda Valerius Maximus'un eserinde (6.1.4'te) $)^{54}$ Maenius'un, azat ettiği kölesini öldürdüğü yazmaktadır. Maenius'un, azatlısını öldürme nedeni ise, kızını öpmesidir. Yazar, olayın hukuki içeriği hakkında bize bilgi vermese de, efendinin azatlısını öldürmesi toplumda ölüm-yaşam hakkının devam edip etmediği hakkında bizi düşünmeye sevk etmektedir. Bu metin dışında Suetonius (Caesar, 48 'te) ${ }^{55}$, Iulius Caesar'ın, azatlısını, süvari sınıfından bir askerin karısı ile zina suçu işlediği için öldürdüğünü ve bunun için herhangi bir ceza almadığını yazmaktadır. Yine Suetonius (Augustus,67'de) $^{56}$, Augustus'un, zina suçuna karışan bir azatlısını, intihara zorladığından ve herhangi bir yargılamaya maruz kalmadığından bahsetmektedir. Metinler, efendinin azatlısı üzerinde ölüm-yaşam hakkının bulunup bulunmadığı konusunda kanaat sahibi olmamızı sağlayamamaktadır. Caesar ve Augustus'un siyasi figür olması ve devletin iktidarını paylaşan magistra'lar olması nedeniyle, azatısını cezalandıran eski efendi sıfatıyla değil, kamu adına cezalandırma yetkisini kullanan görevli sıfatıyla hareket etmiş olabileceği gözden kaçmamalıdır. Bunun dışında Cicero, (ad Quintum fr.1.1.13’te) ${ }^{57}$ ataların, azatlılarına köleleri gibi hâkim olmalarının adetlere dayandığını aktarmaktadır ancak bu yetkinin, ölüm-yaşam hakkına uzandığı (ius vitae et necis)'na ilişkin bir vurgu yapmamıştır.

\section{Obsequim ve Reverentia}

Obsequim ve reverentia yükümlülükleri, Roma'da bir takım ilişkilerin özünde bulunan "pietas" denilen bir kavramın içeriğinden doğardı. Bu kavram Romalıların ilahi güçlere, vatana ve aileye karşı sahip oldukları erdemi ifade etmek için kullanılırdı. Roma ailesinde ise, aile üyelerinin birbirlerine olan davranış biçimini ve 
daha ziyade çocukların atalarına karşı gösterdikleri -itaati de barındıran- saygı dolu davranış biçimini betimlerdi.

Pietas kavramının içini dolduran ve doğal uzantısı olan "obseqium” ile çocukların ebeveynlerine (ve azatlıların kendilerini azat eden efendilerine ve çocuklarına) karşı göstermekle yükümlü oldukları hürmet ifade edilirken, "reverentia" ile çocukların ebeveynlerine ve azatlıların kendilerini azat eden efendileri ile çocuklarına karşı sayg1 gösterme yükümlülüğü ifade edilirdi. Dolayısıyla reverentia'yı obseqium'dan ayrı düşünmek mümkün değildir ${ }^{58}$.

Obseqium borcunun içeriğinin tam olarak ne olduğunu açık bir şekilde tespit etmek çok kolay değildir. Obseqium, "verilen emre uyma, boyun eğme ve siyasi anlamda sadakati" ifade ederdi ve hukuki bir tanımı yapılmamışt1 ${ }^{59}$. Dolayısıyla azatlı ile efendi arasında özellik arz eden bağdan kaynaklanan çeşitli borçlar obsequim'u oluşturabilirdi. Bir örnek vermek gerekirse; efendiye karşı saygı gösterme ve hürmet duyma borcu, azatlının, efendi ile aralarındaki uyuşmazlığın praetor'dan izin almadan yargı önüne taşınmasına, infamia ile sonuçlanabilecek davaları açmasına ${ }^{60}$ (D.37.15.5.1), zilyetliğin iadesini emreden bir interdictum'dan faydalanmasina (D.43.16.1.43) ve hile ve ikrahtan dolayı defi ileri sürmesine müsaade etmezdi (D.44.44.16). Buna benzer şekilde, Lex Pompeia de parricidiis ${ }^{61}$, azatlının eski efendisini öldürmesini birinci dereceden yakın akrabasını ya da aile reisini öldürme suçu gibi düzenlemiş ve cezasını da ölüm olarak belirlemişti (D.48.9.1).

Azatlının obseqium yükümlülüğü ile ilgili bilgiyi D.38.2.1'de bulmaktayız. Metnin principium'unu ve Cicero'nun (ad Quintum fr.1.1.13) metnini birlikte değerlendirdiğimizde, özellikle eski devirlerde, azatlının eski efendiye tabiiyetlerinin devam ettiğini ve yükümlülüklerinin ağır olduğunu anlıyoruz. Bir başka deyişle, eski efendinin azatlı üzerinde varlığını sürdüren egemenlik hakkı, azatlıyı eski efendiye bağımlı kılıyordu. Bu bağımlılık, eski efendinin verdiği her türlü emre itaati gerektirir ve onun isteyeceği her türlü hizmeti görme yükümlüğ̈nü doğururdu. Eski efendilik hakk1 (iura patronatus)'nın müeyyidesi olan "manus iniectio"62, azatlının, eski efendi tarafından istenenlerin yapılmasını sağlamaya yeterli olduğundan, kölenin

\footnotetext{
58 Judith Evans Grubbs, "Promoting pietas through Roman Law", A Companion to Families in the Greek and Roman Worlds, Malden 2011 (edited by Rawson, B.), s. 377

59 Treggiari, s. 73; Adolf Berger, Encyclopedic Dictionary of Roman Law, Pliladelphia 1953, s.605.

60 Söz konusu davalar actiones Famosae olarak da anılırdı; örneğin, actio bonorum vi raptorum, actio furti, actio iniuriarum, actio doli, actio depositi directa, actio fiduciae directa, actio mandati directa, actio pro socio bu çeşit davalardandı. Umur, Lügat, s. 15 .

${ }^{61}$ Parricidium (aile reisini öldürme suçu) tabirini, ana-babanın, büyük ana-babanın, çocukların, torunların, kardeşlerin, eşlerin öldürülmesine teşmil eden kanun. Berger, s. 558.

62 Efendinin, emirlere riayet etmeyen azatlısını zorlamak için sahip olduğu yetkilerden biri idi. Azat ettiği kölesine el koyan eski efendinin, onu kendi evinde yaşayamaya zorlayabildiği bir imkân idi. Jessica Lambert, Operae Liberti, Paris 1934, s. 73. Ayrıca Quintilianus, Institutio Oratoria adlı eserinde efendinin azatlısı üzerinde sahip olduğu yetkilerden manus iniectio'ya değinmiştir. Metin için bkz: http://www.thelatinlibrary.com/quintilian/quintilian.institutio7.shtml\#7.
} 
azat edildikten sonra, "obsequim" borcunu doğuracak şekilde ius civile bakımından geçerli bir hukuki işlemle vaatte bulunmasına gerek kalmıyordu ${ }^{63}$.

Cumhuriyet dönemi ile ilgili olarak ise, Praetor Rutulius'a atfedilen bir edictum ile getirilen düzenleme hakkında bilgi veren D.38.2.1.1 ise yolumuzu aydınlatmaktadır. Metinden anladığımız üzere, azatlı, azat etme muamelesi esnasında obseqium yükümlülüğ̈̈ne uygun hareket edeceği hususunda bir taahhütte bulunmaktadır. Efendi ise bunun karşılığında özgürlük bahşetmektedir. Dolayısıyla, Cumhuriyet döneminde obsequim yükümlülüğüne aykırı hareket etmemesi, her azatlıdan değil ancak taahhüt ile borç altına giren azatlıdan talep edilebilirdi.

Bunun yanı sıra metinden anlaşıldığı üzere, obseqium yükümlülüğünü taahhüt eden köleye hürriyet bahşedilmesi sebebiyle, azatlı ve efendi arasında bir çeşit societas (societas libertatis causa) oluştuğu kabul edilmiştir. Köleye hürriyetini kazandirma gayesiyle oluşan bu ortaklıkta (societas libertatis causa), efendinin payı hürriyeti hediye etmek, azatlının payı ise, obseqium yükümlülüğünün gereğini yerine getirmektir ${ }^{64}$. Azatlının muamele esnasında stipulatio gerçekleştirmek suretiyle taahhüt ettiği yükümlülüğe aykırı hareket etmesi halinde ise, praetor Rutulius efendiye başvurabileceği tek bir imkân bırakmıştır. Edictum'a göre, efendi, dermeyan edebileceği actio societatis ile ancak azatlının malvarlığı üzerinde birtakım haklar elde edebilecektir. Bir başka deyişle efendinin obseqium yükümlülügüune aykırı davranan azatlısına karşı sahip olduğu hakların, praetor Rutulius döneminde yayınlanan edictum ile, kısıtlandığını öğreniyoruz. Zira metinde bu edictum ile getirilen düzenleme gereği, sadece söz konusu yükümlülüğün gereğini yerine getireceği hususunda taahhütte bulunan azatlının borcuna aykırı davranışından söz edilebilecektir. Bunun yanı sıra efendi, azatlısının güven sarsan davranışı ile bozulan societas'a dayanan dava hakkından başka bir imkâna sahip değildir.

Anlaşılacağı üzere, eski hukuk döneminde azat edilen kölenin, eski efendisine olan tabiiyeti, azatlı bakımından daha ağır sonuçlar doğururdu. Bu döneme ait bilgilerimiz çok sınırlı olmakla birlikte, Cumhuriyet döneminde praetor'un edictum ile, azatlının obseqium borcuna aykırı davranması halinde yaptırımın ne olacağı yönünde eski efendiyi sınırlayan bir takım düzenlemelere yer vermesi bize ipuçları vermektedir. Zira D.38.2.1.1, azatlının yükümlülügünü ihlal etmesi halinde, efendinin elinde kalan tek imkân olarak societas'tan doğan davayı anlatmaktadır.

D.44.5.1.5 ise, azatlıyı koruyan hükümlerden bahseden bir başka metindir. Metin, azatlının durumunu haksız bir şekilde zorlaştıran taahhütler ile azatlının özgürlügünü tehdit edecek nitelikte olan ve onu adeta efendisine tabi hale getirecek taahhütlerin (onerandae libertatis causa) içeriğinin talep edilemeyeceğini ifade etmektedir.

\footnotetext{
63 Treggiari, s. 73.

${ }^{64}$ Watson, s. 228; Treggiari, s. 70.
} 
D.44.5.1.6' dan ise, özellikle azatlının özgürlüğüne engel olacak ve onu eski efendisine tabi kılacak şekilde bir yükümlülüğü taahhüt etmeye zorlandığ 1 durumlarda, buna riayet etmeyen azatlıya bir savunma imkânının (exceptio) tanındığg öğreniyoruz ${ }^{65}$. Söz konusu düzenlemeler, efendinin çeşitli sebeplerle özgürlük bahşettiği azatlısını, onun özgürlük statüsünü etkileyecek bir takım taahhütlerde bulunmaya zorlamasının önüne geçmeye yönelik tedbirlerdir.

Bahsedilen bu tedbirlerin ardından, D.44.5.1.7 ve D.38.1.36'ya değinmek yerinde olacaktır. Zira D.44.5.1.7, azatlı ve efendi arasında oluşan societas (societas libertatis causa)'dan doğan davanın, taahhüt ettiği yükümlülüğü yerine getirmediği için azatlıya dermeyan edilmesi halinde, azatlının eski efendinin talebine karşı herhangi bir exceptio ileri sürmesine gerek olmadan, ipso iure korunması gerektiğini yazmaktadır. Bir başka ifade ile metin, eski efendinin societas'tan doğan davayı dermeyan edemeyeceğini ifade etmektedir. D.38.1.36'da ise hukukçu Labeo, azatııın yerine getirmeyi taahhüt ettiği yükümlülüğün, azatlının durumunu haksız bir şekilde zorlaştırıp zorlaştırmadığını dahi mevzubahis etmeden, azatlı ve efendi arasında oluşan societas (societas libertatis causa)'ın hükümsüz olduğunu ifade etmektedir.

Özellikle ilk devirlerde, pater familias örneğinde olduğu üzere patronus'un otonomisine duyulan saygı ve dolayısıyla azatlının eski efendi ile bağının oldukça sık1 olmas1, "obsequim" yükümlülüğünün içeriğinin tam anlamılla saptanamaması sorununu doğurmuş, dolayısıyla, söz konusu borca aykırı davranışın yaptırımı (manus iniectio), azatlıyı, adeta köle gibi yaşam sürdürmeye mecbur bırakmıştır. Ancak aile kurumu gibi, giderek patronus'luk hakkının da değişmesi, eski efendinin azatlı üzerindeki egemenlik hakkını kısıtlamaya başlamışt ${ }^{66}$. Buna paralel olarak azatlının, eski efendisi karşısında durumunu zorlaştıran haller, praetor'un müdahaleleri ile giderilmeye çalışılmıştır. Metinlerden de anlaşılan odur ki, kölesinin hukuki statüsünü değiştirerek ona büyük bir lütuf bahşeden efendinin, bu iyilik karşıllı̆ında taleplerinin karşılanması, azatlıların kazandığı hürriyeti anlamsızlaştırmaya başlayınca, azatlıların hukuki vasıtalarla korunması ihtiyacı doğmuştur. Praetor Rutulius'un getirdiği düzenleme ile sadece belli yükümlülükleri taahhüt eden azatlıların "obsequim" borcuna aykırı davranışından bahsedilebilecektir. Efendinin azatlısını, borcunu ifa ettiği takdirde durumunu zorlaştıracak bir taahhütte bulunmaya mecbur ettiği hallerde ise, praetor bahsettiğimiz başka bir takım vasıtalarla azatlıyı korumuştur. Ancak muhtemelen daha sonraki praetor'lar söz konusu vasıtaların, azatlların kazandıkları hürriyet bakımından yeterli bir koruma sağlamadığı gerekçesi ile, azat etme muamelesi esnasında azatlının taahhüdü ve efendinin hürriyet bahşetmesi ile

\footnotetext{
${ }_{5}$ Yine D.44.5.1.6'dan, azatlının, azat edildikten bir süre sonra kendisini eski efendisine tabi kılacak bir yükümlülüğü, herhangi bir zorlama olmasa da, stipulatio ile taahhüt etmesi halinde, herhangi bir savunma imkânın olup olmadığına tereddütle yaklașıldığını anlıyoruz. Metindeki bilgiler ıșığında, böyle bir durumda, azatlının gösterdiği aşırı hürmet dolayısıyla, kendisini yükümlülük altına sokan ve gereğini yerine getirmediği takdirde de, sorumluluğunu gerektiren bir nevi cezai işleve sahip stipulatio gerçekleştirdiğini kabul etmek uygun olacaktır.

66 Özcan Karadeniz, Iustinianus Zamanına Kadar Roma'da İş İlişkileri, Ankara 1976, s.199.
} 
oluşan societas' 1 ve dolayısıyla efendinin talebine kavuşabilmesinin temeli olan dava hakkını tanımaktan vazgeçmişlerdir ${ }^{67}$.

\section{Operae Libertorum}

Operae libertorum, azatlının hürriyetine kavuştuktan sonra eski efendisi için belirli gün sayısı kadar onun menfaatine yapması gereken hizmetleri veya işleri ifade ederdi ${ }^{68}$. Eski efendiye, azat eden malik sıfatıyla tanınan hakların (iura patronatus) arasında, azatlının operae olarak bilinen yükümlülüğü de yer alırdı. Ancak bu yükümlülüğün yerine getirilmediği hallerde, eski efendi tarafından dava edilebilmesi, azatlının bu hususta bir taahhüdünün bulunmasına bağlıydı. Azatlı, eski efendisi menfaatine hizmet edeceğine dair yemin ederek taahhütte bulunurdu. Dolayısıyla azatlı bu hizmetleri bir yeminle taahhüt etmemişse, azatlının operae libertorum olarak ifade edilen yükümlülüğünden doğan borcu, eksik borç (obligatio naturalis) niteliğinde idi. Azatlı yemin etmemiş olsa dahi kendi isteği ile söz konusu hizmetleri yerine getirebilirdi (D.38.1.31).

Azatlının kendisine hürriyet bahşeden eski efendisine hizmet edeceği ya da bir takım işleri yerine getireceğine dair yemin etmek (iusiurandum) suretiyle taahhütte bulunması (promissio iurata liberti), Roma hukukunda yeminin borç doğurduğu yegâne durumdu (Gaius, 3,96). Henüz azat edilme işlemi gerçekleşmeden, efendisi için bir takım hizmet veya işleri yerine getireceğine dair yemin ederek söz veren kölenin, ettiği yeminin hukuken bir geçerliliği olmadıği için, azat edildikten sonra bu yemini tekrar etmesi usulü yerleşmişti. Ayrıca yemin (iusiurandum)'in fas $^{69}$ ile bağlantısı, bir başka deyişle dinsel niteliği, köleyi söz konusu taahhütlerini azat edildikten sonra hukuken geçerli bir biçimde tekrar etmeye zorlard1 ${ }^{70}$. Azatlı yemin etmek suretiyle taahhütte bulunduğu yükümlülükleri yerine getirmezse, eski efendinin "iudicium operarum" veya "actio operarum" denilen ve azatlisı aleyhine kullanabileceği bir davayı dermeyan etme imkânı doğardi ${ }^{71}$.

Azatlının yemin etmek (iusiurandum) suretiyle taahhütte bulunması (promissio iurata liberti) dışında, eski efendisine karşı yerine getireceği hizmetleri veya işleri,

\footnotetext{
7 Treggiari, s. 71.

68 Umur, Lügat, s. 147; Di Marzo, s.48-49.

69 İlahlar tarafından insanların yapmasına müsaade edilen hareketleri tespit eden ve hilafına hareket edildiği zaman dini cezaları gerektiren din kurallarının yekünü. Umur, Lügat, s. 71.

70 Watson, s. 229.

71 Söz konusu dava, azatlının taahhüt edip de yerine getirmediği işleri zorla yaptırma gayesine yönelik değildi. Yapılmamış olan işler nedeniyle belli bir miktar paranın ödenmesine yönelikti. Zira mahkûmiyetin bir miktar paraya ilişkin olma zorunluluğunun yanı sıra eski efendinin iş konusundaki talep hakkı, iş borcunun zamanında ifa edilmemesi halinde, paraya ilişkin bir talep hakkına dönüştügü kabul edilirdi. Karadeniz, Roma'da İş İlişkileri, s.198 ve s. 208. Azatlının taahhüt edip de yerine getirmediği hizmetin değeri ise, belli bir usulle tartılıyordu. Efendinin, azatlı tarafindan yerine getirileceği taahhüt edilen hizmetten sağlayacağı yarara göre bir değerlendirme yapılması öngörülmüş̧ü (D.38.1.26.1).
} 
stipulatio $^{72}$ ile taahhüt etmesi de mümkündü ${ }^{73}$. Metinlerden anlaş1ldığ 1 üzere her iki usul de uygulamada yer bulmuştu. Ancak D.38.1.10 ve D.38.1.11'de açıkça ifade edildiği üzere, azatlının ettiği yemin (iusiurandum)'den doğan borcun, azatlı tarafından başkalarına devredilmesi mümkün değildi. Zira azatlı, kendisine hürriyetini bahşeden efendisine karşı duyduğu minnetin karşıllğı olarak, yemin ederek taahhütte bulunmaktaydı. Bir başka ifadeyle yeminden doğan borç ilişkisi kişisel nitelikte idi, azatlıyı eski efendisine bağımlı kılıyordu ve azatlı, ancak bizzat hizmet ettiği takdirde, borcunu ifa etmiş sayılırdı. Bu sebeple, azatlının taahhüt ettiği hizmetlerden yararlanma imkânı olmayan eski efendiler, bu hizmetleri ücret karşılığında bir başkasına devretmesi ve bu suretle değerlendirmesi mümkün olmuyordu. Azatlının bazı hizmetleri yerine getirme yükümlüğünün stipulatio'dan doğması halinde ise, taahhüt edilen hizmetlerin başkasına devri mümkündü. Dolayısıyla eski efendiler tarafından, bu usulün daha çok tercih edilmiş olması muhtemeldir.

Bununla beraber azatlının stipulatio ile yerine getirmeyi taahhüt ettiği hizmetlerin, ücret karşılığında bir başkasına devri belli hallerde kabul edilmişti. Bu haller, eski efendinin maddi sıkıntı içine düştüğü veya söz konusu hizmetlerden kendisinin yararlanma imkânının olmadığı durumlardı (D.38.1.25). Ancak Klasik sonrası dönemde yapılan bir ayrımla "opera fabriles" terimi ile ifade edilmeye başlanan bu tür hizmetlerin, stipulatio ile taahhüt edildiklerini ve belli durumlara özgü olmadan da efendi tarafından başkasına devredilebildiklerini görüyoruz ${ }^{74}$. "Opera fabriles" terimi ile ifade edilen hizmetler, vasıflı işgücünü gerektirmekle beraber azatlı yerine başkası tarafından yerine getirebilen (mimarlık ya da hekimlik bilgisini gerektiren meslekler gibi) ve eski efendi yerine bir başkasına da yerine getirilebilecek türdendi (D.38.1.6). "Opera officiales" terimi ile ifade edilen hizmetler ise, eski efendinin her türlü işlerinde ona yardımcı olmak ya da onun ekonomik işlerini yönetmek veya evle ilgili işlerini yönetmek (binanın ya da çiftliğin yönetilmesi) gibi, azatlının şahsının önem kazandığı ve doğrudan eski efendiye karşı yerine getirilmesi gereken hizmetlerdi. Dolayısıyla, bu tür hizmetlerin bir başkasına devri mümkün değildi (D.38.1.38.1; D.38.1.49).

Azatlının yerine getirmeyi taahhüt ettiği hizmetlerin ifa yeri ve zamanı konusunda hukuki metinler bizi aydınlatmaktadır. Azatlı, "operae" borcunu, kural olarak eski efendinin ikamet ettiği yerde ifa etmelidir (D.38.1.21). Azatlı, yükümlülüğünü yerine getirmek maksadıyla efendisinin yerleşim yerine seyahat etmek durumunda kaldı ise, seyahat süresi de hizmet süresi hesaplanırken dikkate alınırdı ve seyahat masrafları eski efendiye ait sayılırd1 (D.38.1.20.1). Bununla beraber aynı metinde

\footnotetext{
2 En eski zamanlardan beri, sözlü şekle tabi tek taraflı, dar hukuk davası doğuran akit. Herhangi bir vaadini geçerli kılmaya elverişli bir vasıta olması ve geniş alanlarda uygulama imkânı verdiği için, özellikle ilk dönemlerde oldukça önemli bir akit tipi idi. Müstakbel alacaklının belli şekilde sorduğu soruya, müstakbel borçlunun uygun cevabı ile oluşurdu. Umur, Lügat, s. 202.

${ }_{73}$ D.38.1.5, D.38.1.10.pr, D.38.1.22 açık biçimde eski efendi ile azatlı arasında yapılan stipulatio' dan bahsetmektedir.

${ }_{74}$ Treggiari, s. 77; Şakir Berki, Roma Hukuku, Ankara 1949, s. 115-116.
} 
ifade edildiği üzere, eski efendinin sürekli bir yerleşim yoksa (sürekli seyahat eden bir gezgin olması gibi), azatlıdan hizmet etmek için onu takip etmesi istenemezdi. Bunun dışında azatlı, eski efendinin istediği zaman zarfinda ona hizmet etmeliydi (D.38.1.24).

Azatlının, efendisi menfaatine kaç gün hizmet edeceğini sınırlayan herhangi bir metin bulunmamakla beraber; D.38.1.16. pr. ve D.38.1.16.1'de ile D.38.1.17'de azatının yerine getireceği hizmetlerin onun yaşı, becerisi ve yeteneği ile uyum sağlaması gerektiği, azatlının hürriyet durumunu zorlaştırmaması gerektiği, haysiyetine ve yaşam tarzına uygun olması gerektiği açıklanmış ve ayrıca azatlının, hayatı ve sağlığ 1 için tehdit oluşturmaması gerektiği de ifade edilmiştir. Bahsedilen husus D.38.1.38'de de ayrıca vurgulanmıştır. Hatta azat edildikten sonra bile fahişelik yaparak hayatını kazanmaya devam eden bir azatlı kadının, aynı hizmeti eski efendisi için vermeye devam etmesinin uygun olmadığ da belirtilmiştir. Buna benzer şekilde metinde, hayatını tehlikeye atmadan hizmet vermesi mümkün olmayan gladyatörün, eski efendisi için bir süre gladyatörlük yapmak üzere taahhütte bulunmasının hukuka uygun olmadığı da yer almaktadır.

Bununla beraber, D.38.1.26'da verilen örneğin burada zikredilmesi gerekir. Zira metinde, kendisi de doktor olan eski efendinin, hasta sayısının azalması ve bundan zarar görmesi riskine karşılık, doktor olan azatlısının tıpla uğraşmasını yasakladığı ve sadece kendisine yardımcı olmasını talep ettiği bir örnek betimlenmektedir. Metin, doktor azatlının söz konusu hizmeti kaç gün yerine getireceği hakkında bize bilgi vermese de, azatlının dinlenmesi için ona vakit verilmesinin gerekli olduğunu ve azatlının sağlığının önemsendiğini anlıyoruz. Efendinin talebinin hukuka uygun olup olmadığı sorusu, hukukçu Alfenus tarafindan olumlu cevaplanmaktadır. Bununla beraber, azatlının efendisine yardımc1 olması "operae" yükümlülüğünün konusunu oluşturabilir. Oysa metinde bahsedildiği üzere, konusunu "tıp faaliyetleri ile uğraşmamak" fiilinin oluşturduğu bir yükümlülük (süre belirtilmemekle beraber) "operae"dan ziyade "obsequium" yükümlügüne konu olabilir. Ancak daha önce işlendiği üzere, praetor edictum'u ile azatlının durumunu haksız bir șekilde zorlaştıran (onerandae libertatis causa) ve özgürlüğünü tehdit edecek boyuta ulaşan taleplerle, azatlıyı adeta efendisine tabi hale getirecek taahhütler hükümsüz kılınmıştı. Anlaşılan odur ki, metinde yer alan örnekte, efendinin amacı azatlının hürriyet durumunu zorlaştırmak değildir. Sadece azatlının faaliyetinden zarar görmeyi önlenmek amacı taşıdığı için olumlu karşılanmıştır. Aksi takdirde, doktor azatlının "tıp faaliyeti ile uğraşması", bir başka deyişle, obsequium yükümlülüğüne aykırı hareket etmesi, azatlının sorumluluğunu doğurmaz. Bu düşüncemizi D.37.15.11'deki metin de doğrulamaktadır. Metinde, eski efendisinin rızasına aykırı olsa da, azatı bir kadının mesleğini sürdürmesinin itaatsizlik (nankörlük) anlamı taşımadığı ifade edilmiştir. Buna benzer şekilde, D.37.14.18'den anladığımız üzere, eski efendi, kendisi ile 
aynı bölgede ve aynı iş alanda faaliyet gösteren azatlısının mesleğini icra etmesini yasaklayamaz.

Bunun yanı sıra "operae" yükümlülüğünü yerine getirmek amacılla efendisinin hizmetinde olan azatlı, eğer ki günlük iaşesini karşılayamayacak halde ise, eski efendi karşılamak ya da azatlıya hizmette bulunduğu her gün için kendi iaşesini kazanabileceği bir vakit tanımak zorundadır ( D.38.1.17 ve D.38.1.18).

Bahsedildiği üzere, azatlının operae yükümlülüğünü hizmet etmek suretiyle yerine getirmesi beklenirdi. Azatlının eski efendisine bizzat hizmet ederek operae borcunu yerine getirmesinin bir kural olmas $1^{75}$, kendisini azat eden efendisine duyduğu minnet duygusunun karşılığı olarak düşünülmesinden kaynaklanırdı. Eski efendinin vefat etmesi halinde, azatlının operae borcunu, efendinin mirasçıları olan çocuklarına hizmet ederek yerine getirmesi beklenirdi. Ancak azatlının eski efendi ile anlaşarak, belli bir meblağ karşılığında bu yükümlülükten kurtulması da mümkündü (D.38.1.12). Bununla beraber efendinin, azatlısını, yerine getireceği operae yükümlülüğünü para ödeyerek telafi etmeye zorlamaya ve bu yöntemle onu kendisine bağlamaya çalışmasına ve azatlısının hürriyet durumunu zorlaştırmasına müsaade edilmemiştir (D.38.1.38). Augustus döneminde çıkarılan lex Aelia Sentia aynı hükmü içermektedir (D.40.9.32.1).

Azatlının yerine getirmek için daha önce yemin etmiş olsa dahi operae borcundan muaf tutulduğu haller de vardır: Azatlı kadının yaşının elliden fazla olması hali (D.38.1.35); azatlının iki veya daha fazla çocuk sahibi olması hali (D.38.1.37); azatlı kadının efendisi ile (veya efendisinin rızası ile bir başkası ile) evlendiği veya concubinatus ilişkisi içinde olduğu hallerde (D.38.1.28; D.38.1.46), azatlı bir kadının efendisi için yerine getireceği hizmetin onun onuru ve sosyal statüsü ile bağdaşmayacağı hallerde; azatlının hastalanması halinde (D.38.1.34); eski efendinin azatlının istediği iaşeyi sağlamaması veya ona ihtiyaçlarını karşılayacağı bir zaman bırakmaması hali (D.38.1.20); eski efendinin capitis deminutio'76ya uğraması hali. Metinlerde örnekleri verilmek suretiyle bahsedilen bu hallerde, azatlının, operae borcunu yerine getirmemesi sorumluluğuna yol açmazd1.

\section{Bona}

XII Levha Kanunu'nda, azatlının vasiyetname bırakmadan ölmesi ve suus heres mirasçısının da olmaması durumunda, mirasın eski efendiye ait olacağına dair hüküm yer almaktadır. Bu kural praetor'un miras hukuku alanında düzenlemesinden sonra

\footnotetext{
Bazı hallerde azatlının eski efendisi haricinde onun arkadaşlarına da hizmet etmesi olağan karşılanırdı. D. 38.1.27'de de ifade edildiği üzere, azatlının balet olması gibi eğlence alanına hitap eden bir mesleği icra ediyor olması durumunda efendi ile arkadaşlarına hizmet etmesi hali ya da doktor azatlının hizmetinden kendisinin yararlanmasının gerekli veya mümkün olmadığı hallerde, efendinin isteği üzerine, doktor olan azatlının eski efendinin arkadaşlarına hizmet etmesi hali gibi.

76 Karadeniz, Roma'da İş ilişkileri s. 211. Ayrıca Capitis deminutio ile ilgili detaylı bilgi için bkz: "Roma Hukuku'nda Capitis Deminutio", çev. G. Burcu Günveren, Marmara Üniversitesi Hukuk Araştırmaları Dergisi, C.19, S.1, s. 393-402.
} 
değişmişti. Gaius'un aktardığına göre, azatlı vasiyetname düzenlemek suretiyle mirasının yarısı üzerinde dilediği tasarrufta bulunabilirdi. Bununla beraber azatlı malvarlığının diğer yarısını, eski efendiye ait olacak şekilde bir düzenleme yapmak zorundayd1. Eski efendiye sahip olduğu paydan daha azı tahsis edilir ya da herhangi bir şey tahsis edilmemek suretiyle mirasa iştirak etme hakkından mahrum bırakılırsa, efendiye, mahrum bırakıldığı kısım için tereke üzerinde bonorum possessio ${ }^{77}$ tanınmıştı. Eski efendinin ölümü halinde ise, mirasa iştirak hakkı eski efendinin erkek altsoyuna geçerdi. Bonorum possessio'dan eski efendinin ölümü halinde erkek alt soy da yararlanırdı (Gaius, Inst.3.45). Oysa XII Levha Kanunu'nda bonorum possessio' dan yararlanma hakkı bakımından, eski efendinin, kız ya da erkek alt soyu olması farketmezdi (Gaius, Inst.3.46).

Azatlının vasiyetname düzenlemeden vefat etmesi halinde ise, suus heres mirasçılarının arasında evlat edinilmiş bir çocuk ya da hâkimiyeti altında olan karısı varsa, aynı şekilde eski efendi terekenin yarısı üzerinde hak sahibi sayılırdı. Bir başka ifadeyle, azatlının sadece biyolojik çocuğu, eski efendinin mirasa iştirak hakkını önleyebilirdi. Üstelik azatlının biyolojik çocuğunun ölüm anında azatlının patria potestas' 1 altında olması da gerekmezdi. Azatlı, hâkimiyetten çıkardığı ya da evlatlık verdiği çocuğunu mirasçı atamak suretiyle, eski efendisini mirastan mahrum edebilirdi. Azatlı bu kişileri mirasçı atamadığı gibi, mirastan mahrum da etmezse, mirasç1lar bonorum possesio contra tabulas ${ }^{78}$ a başvurabilirlerdi. Ancak mahrum edildikleri takdirde, eski efendinin mirasa iştirak etmesinin önüne geçilemezdi (Gaius, Inst., 3.40).

Azatlı, eski efendisinin mirasa iştirak etme hakkını ihlal edecek şekilde, hileye başvurarak sağlar arasında (ya da muayyen mal vasiyeti yapmak suretiyle) tasarrufi işlemler yapacak olursa, eski efendi kendisine zarar verdiği oranda bu muamelelerin iptalini actio Fabiana ya da actio Calvisiana ile isteyebilirdi ${ }^{79}$ (D.37.14.16. pr). Azatlının hile saiki ile hareket etmesi söz konusu ceza davalarının mahkûmiyetle sonuçlanması için yeterli idi. Bir başka deyişle, azatlının muameleleri gerçekleştirdiği kimselerin iyiniyetli ya da kötü niyetli olması davanın sonucunu etkilemezdi.

\footnotetext{
Bonorum possesio, ölmüş bir kimsenin bıraktığı malların tamamının veya bir kısmının zilyetliğinin, praetor tarafından, ius civile' ye göre mirasçı olamayacak bir şahsa verilmesidir. Aynı zamanda zamanaşımı ile iktisaba götüren bu zilyetliği talep eden şahsın, müteveffaya ait terekenin tamamını veya bir kısmını elde etmesinin mümkün olması için, praetor'un, bunu, hakkaniyete uygun bulması gerekirdi. Umur, Lügat, s.29.

78 Bonorum possesio contra tabulas; Müteveffa, yapmış olduğu vasiyetnamede, füruu arasından bazılarını mirasçı olarak atamamış ya da usulüne uygun olarak mirastan iskat etmemișse, praetor, vasiyetnamedeki tasarruflar aleyhine, o șahıslara terekedeki malların zilyetliğini vermesi. Erkan, Küçükgüngör, Roma Hukukunda Vasiyetname (Testamentum), Ankara 2007 , s.79 vd.

79 Berki, s. 117, dipnot 1.
} 


\section{B. Azatlı ile Doğuştan Hürler ${ }^{80}$ (Ingenuus) Arasındaki İlişskiler Bakımından}

Hürriyetlerini kazanmalarına rağmen, daha önce köle olmaları azatlıların yaşamlarını olumsuz şekilde etkilerdi. Konumuzun kapsamı dışında kalmakla beraber, ifade etmemiz gerekir ki, kamu hukuku alanında azatlı, doğuştan hür bir Romalının sahip olduğu yetkilere sahip değildi. Örneğin seçilme hakları (ius honorum) yoktu, seçme haklarını (ius suffragii) kısıtlı kullanırlardı. Bir başka ifade ile kamu hukuku alanında ehliyetleri kısıtlı idi.

Özel hukuk alanında ise ius civile'ye özgü hukuki muameleleri yapma hakkına (ius commercii)'ye sahip oldukları kabul edilirdi. Vasiyetname düzenleyebilir ve herhangi bir mal üzerinde mülkiyet hakkına sahip olabilirlerdi ${ }^{81}$.

Azatlılar da diğer Roma vatandaşları gibi (ius conubii) evlenme hakkına sahipti ${ }^{82}$. Conubium, ius civile'ye göre geçerli bir evlenme yapmak için tarafların evlenme ehliyetine sahip olmasını ifade ederdi ${ }^{83}$. Conubium'un bulunmaması evliliğin geçerliliğini ve söz konusu birliktelikten doğan çocukların hukuki durumunu etkilerdi. Azatlılar sosyal hayatta en büyük olumsuzluğu bu alanda yaşarlardı. Zira doğuştan hür olanlar ile azatlılar arasındaki evliliklerin, yasal olduğu kabul edilse ve bu evlilikler cezaya maruz bırakılmasa da, Roma toplumunun hiçbir döneminde sözkonusu evliliklere sıcak bakılmazd $1^{84}$. Buna rağmen özellikle hür bir erkek ile azatlı kadın arasındaki evliliklerin en azından Augustus dönemine kadar yaygın olduğu anlaşılmaktadır. Öyle ki daha önce bahsettiğimiz üzere, Lex Aelia Sententia ile köle azat etmelere getirilen yaş sınırının bir istisnası olarak, azatı kadınla evlenmek üzere yapılan azat etmeler kabul edilmişti. Aynı husus D.23.2.23'de de ifade edilmektedir.

Augustus döneminde ise evlenmeyi düzenleyen kanunla (Lex Iulia de Mariendis ordinibus) senatus üyelerinin ve onların üç nesil kadın ve erkek alt soylarının azat edilmiş kimseler ve belirli başka kimselerle evlenmesini yasaklamışt1 ${ }^{85}$. Bir başka deyişle söz konusu kanun, azatlılar ile senatus sınıfına dâhil olanlar arasında bir evlenme engeli getirmişti. Azatlıların hür kimselerle evliliğinden ziyade, saygın üst sınıfa mensup kimselerle evliliğine karşı getirilen bu düzenleme, Roma toplumundaki sosyal hiyerarşinin hukuki karşılık bulmasından ibaretti ${ }^{86}$. Augustus'un, üst sınıfin sahip olduğu sosyal statüyü bu düzenleme ile koruma çabası ve getirdiği evlenme

\footnotetext{
${ }^{80}$ Burada kastedilen eski efendi dışında kalan hür kimselerdir. Zira daha "A" başlığı altında, azat etmenin hukuki sonuçları, azatlı ile eski efendi arasındaki ilişkiler bakımından incelenmiștir.

${ }^{81}$ Bülent Tahiroğlu / Belgin Erdoğmuş, Roma Hukuku Dersleri, Tarihi Giriş, Hukuk Tarihi, Genel Kavramlar, Usul Hukuku, İstanbul 2012, s.152.

82 Richard Honig, Roma Hukuku, çev. Şemseddin Talip, Roma Hukuku, İstanbul 1938, s.138-139.

83 Seldağ Güneş-Ceylan, Roma Hukukunda Evlenme, İstanbul 2010, s. 65.

${ }^{84}$ Buna benzer şeklide MÖ. 3. yüzyıl sonlarında zengin bir kadının, kendi sınıfı dıșından bir erkekle evlenmesine vasisi tarafından izin verilmemesi, haklı bir neden olarak görülüyordu. Jane Gardner, Women in Roman Law and Society, London 1986, s.33.

85 Gardner, s.32.

86 Fulya İlçin Gönenç, Roma Hukukunda Kadın, İstanbul 2010, s. 104
} 
engeli, Iustinianus döneminde, düşük olan doğum oranları ve nüfusun azalması gibi endişeler nedeniyle ortadan kaldırılmıştı ${ }^{87}$.

\section{Sonuç}

Çağın tüm uygarlıklarında görüldüğü üzere, iktisadi ve sosyal sisteminin bir gereği olması nedeniyle, Roma toplumunda da kölelik müessesesi mevcuttu ve Roma devletinin siyasi devirleri boyunca varlığını korumuştur. Zamanla çeşitli dinamiklerle değişen Roma toplum yapısı içinde, kölelerin sosyal-ekonomik yaşamı da devirlere göre farklılık göstermiştir. Bununla beraber, köleleri, hürriyet bahşetmek suretiyle, Roma civitas'ına dâhil etme imtiyazı ve imkânı, çok eski devirlerden itibaren tanınmıştı. Bunun yanı sıra, kölelere hürriyet bahşederek, onları azat eden muamelelerinin çeşitli olması da, Roma'da kölelik sisteminin katı olmadığına kanıt teşkil etmektedir. Özellikle, çeşitli yetenekleri, bilgi ve sermaye birikimleri ile köle toplumunda sivrilenlerin azat edilmesi, toplum yapısını güçlendirmiştir. Roma devletinin, seçkin köleleri, azat ederken onlara vatandaşlık da tanıyarak, topluma entegre etme politikası; kısa bir sürede, küçük bir şehir devletinden imparatorluk sınırlarına ulaşmasına katkıda bulunmuştur. Zira ius civile’nin aradığı muamelelerden biri ile, hürriyetine kavuşan azatlı, vatandaşlık da kazandığı için, Roma toplumsal ve siyasal yaşamının bir parçası sayılırdı. Hayatının bir aşamasında köle olması, azatlının devam eden yaşamında, bir takım olumsuzluklar ve kısıtlamalar ile karşılaşmasına neden olsa da, azatlının azat edildikten sonra dünyaya gelen çocukları, bir başka deyişle, azatlının alt soyu, kural olarak, söz konusu olumsuzluk ve kısıtlamalarla da karşılaşmazd1.

Hukuki açıdan köleyi, res mancipi mal statüsünden, hak ehliyetine sahip "kişis" statüsüne geçirmek gibi, oldukça önemli sonuçlar doğuran azat etme muamelelerine, kamu otoritesinin müdahalesi kaçınılmaz olmuştu. Bir başka ifadeyle, azat etme muamelelerinde istenen hukuki sonuç, efendinin hürriyet bahşetme iradesine, kamu otoriterlerinin müdahalesinin eklenmesi ile doğardı. Bu şekilde, Roma devleti, layık bir vatandaşın siyasi örgüte katılmasında söz sahibi olurdu. Diğer yandan Roma devleti, efendinin otonomisinin güçlü ve efendi-azatlı arasındaki bağın yakın olduğu, ilk dönemlerde, eski efendilik hakkı (iura patronatus) hususunda suskun kalmıştı.

Azatlının, hürriyete kavuşması sebebiyle, hizmetinden ve varlığından yoksun kalan efendisine karşı, "pietas" ve "fides" temellerine dayanan, bir takım yükümlülükleri olması olağan karşılanırdı. Bu yükümlülükler, efendisine saygılı davranarak, onun emirlerine itaat etmesi (obsequim ve reverentia) ve gerektiğinde efendisine hizmet etmesi (operae) idi. Azatlının, eski efendisinden daha önce vefat etmesi halinde ise, efendinin, terekeye iştirak etmesi (bona) söz konusu idi. Bununla beraber, özellikle

Treggiari, s. 86. 
obsequim yükümlülüğünün kapsamının belirlenmemiş olması, ilk dönemlerde, azatlının, eski efendisine tabiiyetine bile yol açabilmekteydi. İlerleyen devirlerde ise, Roma aile yapısındaki değişim nedeniyle, patria potestas'ın erezyona uğramasına benzer şekilde, efendilerin de, eski gücünü ve hâkimiyetini yitirdiğini söylemek yanlış olmaz. Zira çalışmamızda açıkladığımız üzere, eski efendilerin, azatlılarına karşı sahip oldukları, eski efendilik hakkı (iura patronatus)'nın içeriğinin, praetor'un müdahaleleri ile tespit edilmeye çalışıldığını ve azatlıların tabiiyetinin önüne geçildiğine tanık oluyoruz. Cumhuriyet dönemi praetor'larından Rutulius'a atfedilen bir edictum ile getirilen düzenleme hakkında bizi bilgilendiren D.38.2.1.1 ve D.44.5.1.5, eski efendisine karşı, azatlının durumunun güçlendirildiğini ifade etmektedir. Söz konusu düzenleme, haksız bir şekilde, azatlının durumunu zorlaştıran ve azatlının özgürlügünü tehdit edecek boyuta ulaşan taleplerle, onu, adeta efendisine tabi hale getirecek taahhütleri (onerandae libertatis causa), hükümsüz kılmıştır. Bunun yanı sıra, miras hukuku alanında da, praetor'ların getirdiği düzenlemelerle, azatıııın durumu iyileştirilmiştir.

\section{Kisaltmalar}

Aulus Gellius, N.A.: Aulus Gellius, Noctes Atticae

Bkz. : Bakınız

bs. : Bas1 - Bask1

çev: Çeviren

C. : Cilt

Cicero, Att.: Cicero, ad Atticum

D.: Digesta

dn. : Dipnot

fg.: Fragmentum

Gaius, Ins.: Gaius, Institutiones

M.Ö.: Milattan Önce

pr.: principium

s. : Sayfa

S. : Say1

Ulp, Reg.: Ulpianus, Regulae

vd. : ve devamı 


\section{Kaynakça/References}

Akşit, Oktay, Roma İmparatorluk Tarihi, İstanbul 1985.

Berger, Adolf, Encyclopedic Dictionary of Roman Law, Pliladelphia 1953.

Berki Şakir, Roma Hukuku, Ankara 1949.

Buckland, William Warwick, The Roman Law of Slavery, New Jersey 2000.

Çelebican, Özcan, "Roma Egemenliği: Yurttaşlık ve Kölelik”, Ankara Üniversitesi Hukuk Fakültesi Dergisi, 1943, C. 43, S.1, s. 299-311.

Daube, David, “Two Early Patterns of Manumission”, Journal of Roman Studies, C.36, London 1946.

Di Marzo, Salvatore, S., Roma Hukuku, çev. Ziya Umur, İstanbul 1959.

Duff, Arnold M., Freedman in the Early Roman Empire, Oxford 1928.

Gardner, Jane, Women in Roman Law and Society, London 1986.

Gönenç, Fulya İlçin, Roma Hukukunda Kadın, İstanbul 2010.

Gönenç, Fulya İlçin, “Roma’nın Vatandaşlık Politikası”, Prof. Dr. Necip Kocayusufpaşaoğlu için Armağan, Ankara 2004, s. 559-673.

Grubbs, Judith Evans, "Promoting pietas through Roman Law", A Companion to Families in the Greek and Roman Worlds, Malden 2011 (edited by Rawson, B.).

Güneş-Ceylan, Seldağ, Roma Hukukunda Evlenme, İstanbul 2010.

Günveren, Güzide Burcu, "Roma Hukuku'nda Statuliber", Marmara Üniversitesi Hukuk Fakültesi Hukuk Araştırmaları Dergisi, Prof. Dr. Cevdet Yavuz'a Armağan, C. 22, S: 3, 2016, s.12411257.

Günveren, Güzide Burcu, "Roma Hukuku'nda Capitis Deminutio", çev. Günveren, Güzide Burcu, Marmara Üniversitesi Hukuk Araştırmaları Dergisi, C.19, S.1, s. 393-402.

Honig, Richard, Roma Hukuku, çev. Şemseddin Talip, Roma Hukuku, İstanbul 1938.

Karadeniz, Özcan, “Iustinianus Zamanına Kadar Roma’da İş İlişkileri”, Ankara 1976.

Karadeniz-Çelebican, Özcan, Roma Hukuku, Tarihi Giriş-Kaynaklar-Genel Kavramlar-Şahsın Hukuku-Hakların Korunması, Ankara 1997.

Kaser, Max, Römische Privatrecht, Munich 1955.

Kayak, Sevgi, Roma Ceza Yargılama Hukukunda Sorgulama ve Cezalandırma Yöntemleri”, Prof. Dr. Belgin Erdoğmuş’a Armağan, İstanbul 2011, s.155-185.

Küçükgüngör, Erkan, Roma Hukukunda Vasiyetname (Testamentum), Ankara 2007.

Lambert, Jessica, Operae Liberti, Paris 1934.

Levy-Bruhl, Henry, Quelques problèmes du très ancien droit romain, "L'affranchissement par la vindicte", Paris 1984.

Mommsen, Theodor, Römisches Staatsrecht, Leipzig 1887.

Okandan, Recai, Roma Amme Hukuku, İstanbul 1944.

Sarıtaş Özer, Duygu, Cumhuriyet Dönemi Roma Vergi Sistemi, İstanbul 2012.

Tahiroğlu, Bülent / Erdoğmuş, Belgin, Roma Hukuku Dersleri, Tarihi Giriş, Hukuk Tarihi, Genel Kavramlar, Usul Hukuku, İstanbul 2012.

Tahiroğlu, Bülent, Roma Hukuku Dersleri, Tarihi Giriş- Hukuk Tarihi- Genel Kavramlar- Usul Hukuku, İstanbul 2012.

Tahiroğlu, Bülent, "Roma Hukukunda Azat etmenin Tahditleri”, İstanbul Üniversitesi Hukuk Fakültesi Mecmuas1, C.38, S.1-4, 1973, s. 521-546. 
Türkoğlu, Gökçe Halide, “Roma Hukukunda Censor'lar”, Prof. Dr. Belgin Erdoğmuş’a Armağan, İstanbul 2011, s. 255-267.

Treggiari, Susan, Roman Freedmen During The Late Republic, Oxford 1969.

Umur, Ziya, Roma Hukuku Lügat1, İstanbul 1983.

Umur, Ziya, Tarihi Giriş- Kaynaklar-Umumi Mefhumlar- Hakların Himayesi, İstanbul 1974.

Umur, Ziya, Roma Hukuku Ders Notları, İstanbul 1999.

Villey, Michel, Roma Hukukunun Güncelliği, Çev. TAHİROĞLU, B., İstanbul 1985, s. 75;

Visky, Karoly, "Roma Hukukunda Kölelik ve Serbest Meslekler”, Çev. TAHİROĞLU, B., İstanbul Üniversitesi Hukuk Fakültesi Mecmuası, 1974, C. 40, S.1-4, s. 689-700.

Watson, Alan, The Law of Persons in The Later Roman Republic, Oxford 1967. 
